\title{
The Nordic Gender Effect at Work
}

Nordic experiences on parental leave, childcare, flexible work arrangements, leadership and equal opportunities at work 


\section{The Nordic Gender Effect at Work}

Nordic experiences on parental leave, childcare, flexible work

arrangements, leadership and equal opportunities at work

Nordic Information on Gender (NIKK)

Nord 2019:058

978-92-893-6413-3 (PDF)

978-92-893-6414-0 (EPUB)

http://doi.org/10.6027/NO2019-058

(c) Nordic Council of Ministers 2019

Layout: Mette Agger Tang

Infographics: Essensen

\section{Nordic co-operation}

Nordic co-operation is one of the world's most extensive forms of regional collaboration, involving Denmark, Finland, Iceland, Norway, Sweden, the Faroe Islands, Greenland, and Åland.

Nordic co-operation has firm traditions in politics, the economy, and culture. It plays an important role in European and international collaboration, and aims at creating a strong Nordic community in a strong Europe.

Nordic co-operation seeks to safeguard Nordic and regional interests and principles in the global community. Shared Nordic values help the region solidify its position as one of the world's most innovative and competitive.

\section{Nordic Council of Ministers}

Nordens Hus

Ved Stranden 18

DK-1061 Copenhagen

www.norden.org

Download Nordic publications at www.norden.org/nordpub 


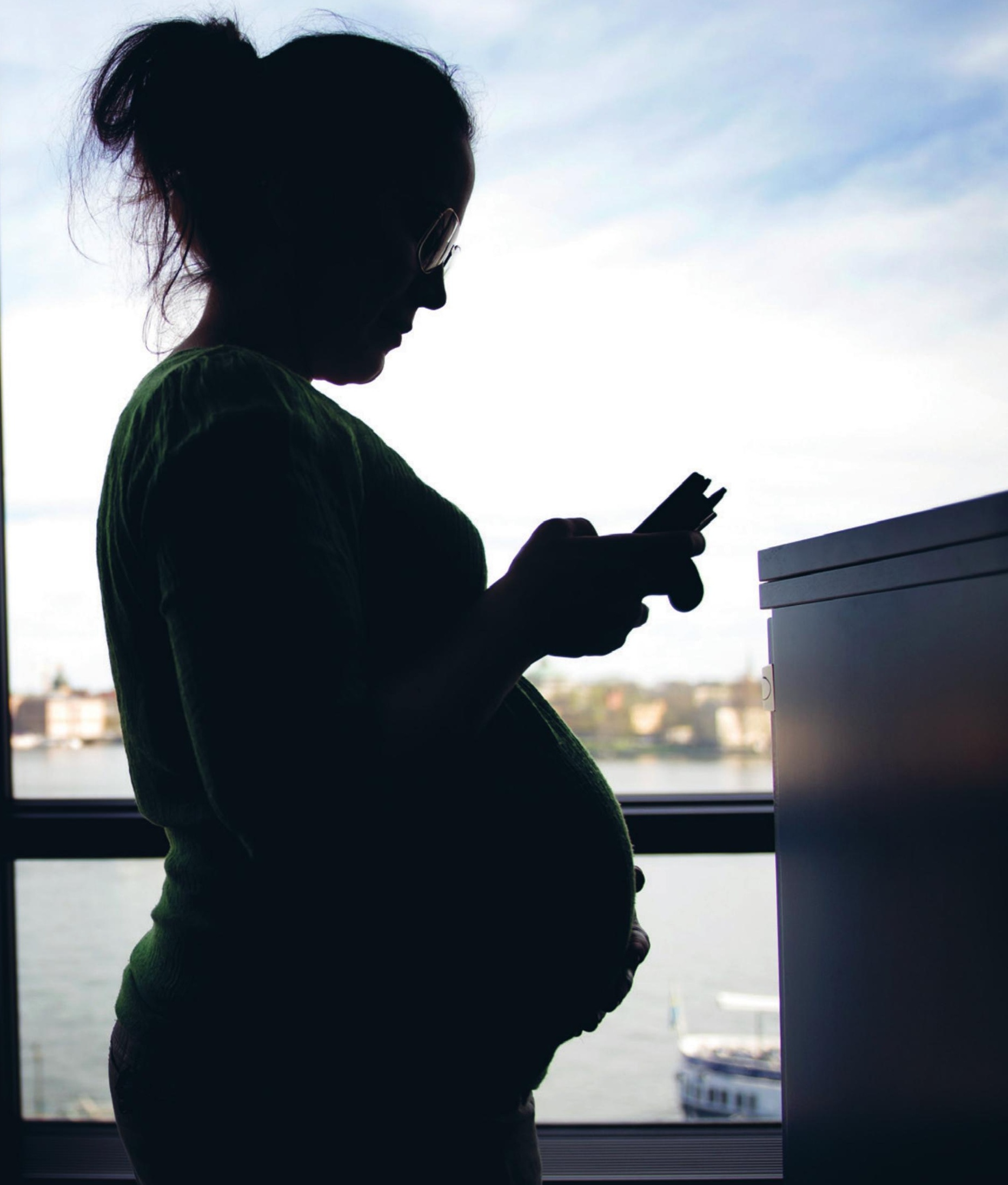





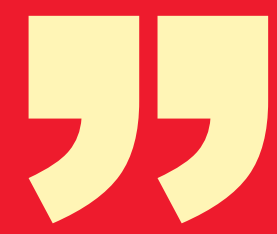

Promoting gender equality at work is not only the right thing to do, but the smart thing to do. 
Investments in gender equality in the labour market have made the Nordic region one of the most prosperous areas of the world. The share of women who work in the Nordic countries is larger than the global average, which is partly the effect of commitments to equal workplaces, subsidised childcare and generous parental leave. With The Nordic Gender Effect at Work briefs, the Nordic region seeks to share its collective experience in promoting gender equality at work, and enable more knowledge sharing and progress towards the UN's 2030 Agenda for Sustainable Development. 


\section{Briefs}

09 Introduction

17 Subsidised childcare for all

27 Shared and paid parental leave

35 Flexible work arrangements

43 Leadership and equal opportunities at work

52 Sources

55 About 


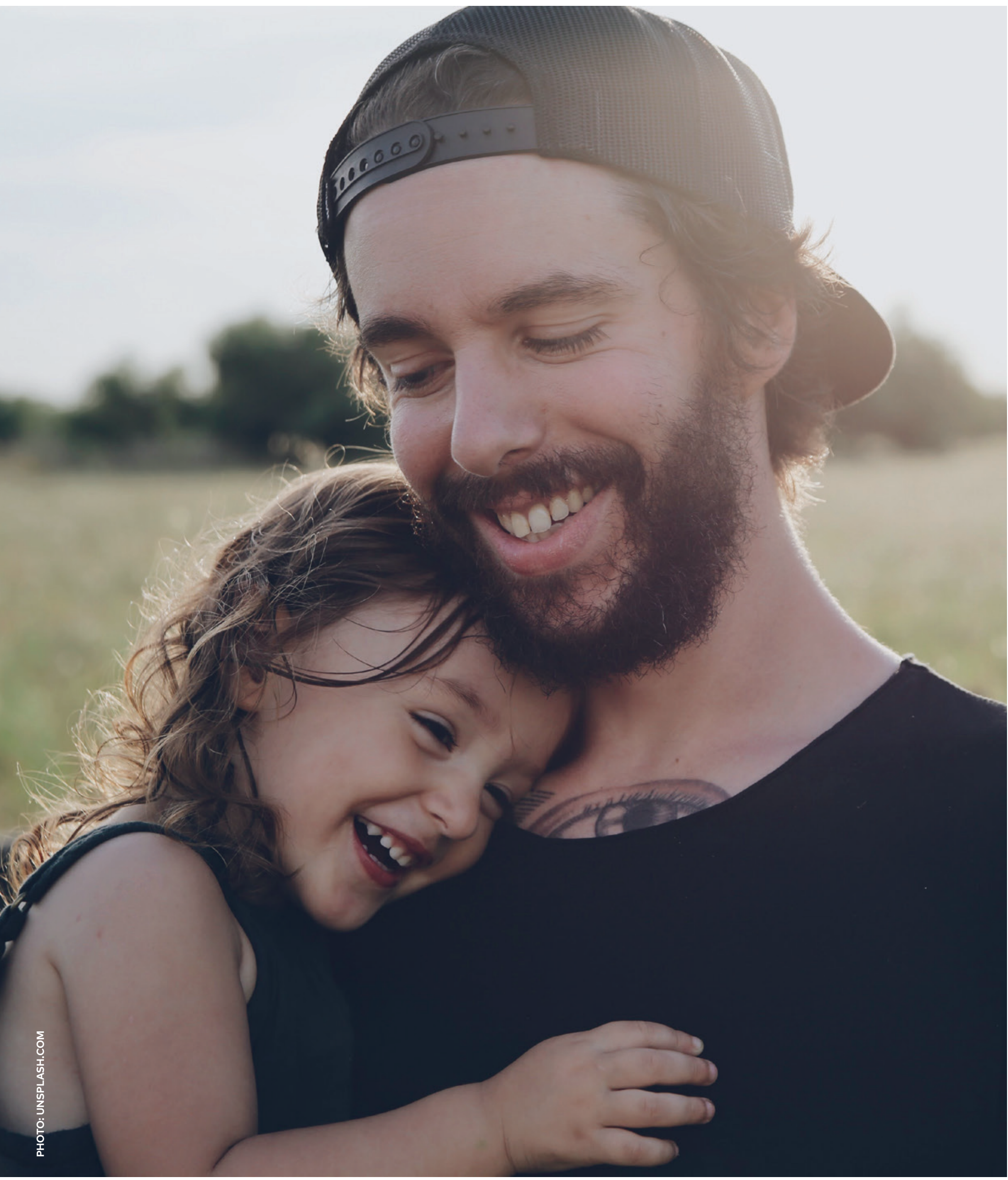




\title{
Introduction
}

\author{
A large share of the world's women remain excluded from the \\ labour market. In fact only half of all women participate in the \\ global labour force, compared to three quarters of men. And there \\ are wide regional variations. The employment rate for women in \\ the Nordic region stands out globally at 73.5 per cent.
}

When it comes to care responsibilities, the uneven sharing between women and men, compounded by absence of maternity protection and affordable childcare, is a big driver of gender inequalities in the labour market the world over. In the European Union, a region with relatively high wages and labour force participation for women, working men spend less than half as many hours on housework as working women.

Globally, women earn approximately 84.4 per cent of what men earn. Women are far more likely to be in low-wage jobs, and often in the informal economy. The International Labour Organization (ILO) has noted that, at the current rate, pay equity between women and men will not be achieved until 2086. The pace of change is simply too slow. These inequalities constitute serious barriers to women's economic empowerment, and indeed to international development at large. It is economically inefficient and ultimately costly for companies and countries alike. In order for the world to progress socially and economically - so as to fulfil the overriding 2030 Agenda objective of leaving no one behind - the entire population and its collective talents must be utilised.

\section{Together we are stronger}

The Nordic countries have collaborated in promoting gender equality for over 40 years. Each of the Nordic countries has extensive experience in advancing initiatives and legislation that facilitate gender equality in the labour market. While there are differences between the countries, the Nordics have been and remain united by a proactive and wide-ranging policy platform on promoting equality between women and men.

Solutions for parental leave, childcare, flexible work arrangements and equal opportunities in the workplace have not evolved organically. The Nordic countries' favourable position internationally in relation to these issues is the result of targeted policies by governments, backed up by well-organised civil society organisations and a private sector that also benefits from social trust and equality.

Over time these models and measures have been key to progress on gender equality in the world of work. The most visible result is that the majority of women in the Nordic countries are in paid employment, almost on a par with men. Nordic efforts have also led to a more gender-equal distribution of power, influence and resources in the region, from politics to businesses. This is "the Nordic Gender Effect".

Despite the strong and consistent focus on gender equality in the Nordic countries, gender inequalities do persist. The Nordic countries are grappling with high levels of occupational segregation in the labour market - both vertically and horizontally - as well as a substantial gender pay gap that is narrowing far too slowly. The region does not have all the answers, and in a number of areas (occupational segregation being a case in point) countries in other regions are performing better. 
As part of the Nordic ambition to contribute to the UN's 2030 Agenda for Sustainable Development, both globally and at home, the Nordic prime ministers have launched "The Nordic Gender Effect at Work" initiative. It is closely linked to the UN's Sustainable Development Goals (hereafter SDGs), which are to be achieved by 2030, and in particular the goals and targets concerning gender equality and the empowerment of women and girls (SDG5) and economic growth and decent work for all (SDG8). This series of briefs describes how the Nordic welfare model and solutions to ensure women's participation in the Nordic labour markets came about, and it seeks to further the international debate on gender equality and serve as a basis for our common efforts towards the SDGs.

\section{Historical overview and key milestones}

The Nordic countries are known to be economically strong welfare states with well-developed social protection systems and high standards of living. However, just 100 years ago, this was not the case. Like much of nineteenth century Europe, the Nordic countries had been involved in several wars and have a long history of poverty and epidemics. Large changes came in the wake of the Industrial Revolution, which created a large working class with poor working conditions and long working hours. Child labour was common. During the second half of the 19th century, trade unions were formed and a labour movement fighting for better conditions emerged. Trade unions grew stronger by joining forces and they soon began to break new ground. Consensus building through collective bargaining between trade unions and employers began to result in better working conditions.

Around the same time, the Nordic women's movements started to grow, advocating for equal rights regardless of gender, and they have paved the way for current levels of gender equality in the region. As similar issues were discussed and pursued across the Nordic region, the national women's movements could benefit from each other's successes and develop their argumentation and negotiation skills. Both the Nordic women's movements and the trade unions started collaborating early. Support was also offered by some Nordic political parties in pursuing progressive legislative reforms, the most notable being the right to vote - achieved in all five countries between 1906 and 1919 .

\section{Women's economic independence}

The issue of women's economic empowerment and independence was discussed at different levels of society in the Nordic region throughout the 20th century. Chief among the political reforms were the new marriage laws, introduced in the 1920s. The laws removed men's guardianship of their wives and gave married women full rights to own property. This, alongside the right to vote,

\section{Nordic cooperation}

Includes Denmark, Finland, Iceland, Norway

and Sweden as well as the Faroe Islands, Greenland and Åland. The formalised cooperation between the Nordic countries is considered one of the most extensive regional collaborations in the world.

The official cooperation takes place within the framework of the Nordic Council of Ministers, where the governments work together through a number of ministerial councils. The framework also includes the Nordic Council, which is the main forum for elected parliamentarians to collaborate.

The ministerial council that covers the policy area of gender equality, namely the Nordic Council of Ministers for Gender Equality. (MR-JÄM), has worked together for more than 45 years. 
was one of the most important issues to the women's movements. In effect, it removed the last male advantage in family law. At the same time, however, women typically had to stop working when they got married. It was a commonly held view that it was unnecessary for married women to work, as there was a risk they would push men out of the labour market. In 1939, Sweden became the first European country to forbid employers from firing women because of engagement or marriage. This was an important reform that affected married women's opportunities to participate in the labour market.

Taxation was another large impediment to gender equality. The joint taxation of spouses meant that spouses' incomes were combined and taxes calculated on the basis of the total household income. The taxes were often so high it hardly made sense for the wife to work. In addition, if both spouses worked, they often had to pay for childcare and a domestic worker to take care of the housework. The introduction of individval taxation, in 1971 in Sweden and Denmark, changed this and created a stronger financial incentive for married women to join the labour force, effectively ending the housewife era.

\section{Women's broad entry into the labour market}

Denmark, Norway and Sweden experienced a severe labour shortage in the 1960-70s. In response, they started to admit labour from other countries and began introducing policies that would increase women's participation in the labour force more forcefully. In Iceland, married women also entered the labour market in the 1960-70s, joining the unmarried women who were already in paid employment. The situation was different in Finland at the time, where a large share of women were already working full time. World War II had been a turning point for the Finns in this respect, causing a labour shortage and seeing more women enter into paid work.

It was in the 1960-70s that the Nordic countries began to introduce specific solutions for childcare. In 1964, Denmark became the first country to legislate on childcare, followed by Finland, Iceland and Sweden in 1973 and Norway in 1975. Childcare was mainly made available to families in which both parents worked full-time. The laws were important components of Nordic family policy at the time, and the intention was for the childcare services to be affordable, flexible and of high educational value to the children. The public sector was dramatically expanded around the same time, creating a large number of job opportunities in education, healthcare and other care services - sectors that came to employ mainly women.

Since the 1970s, the Nordic countries have created a societal and economic structure that enables women and men to participate in the labour

\section{The Nordic model}

The Nordic countries are characterised by a wide-reaching public sector, which is mainly tax-funded. The social protection system is based on the principles of universality and inclusiveness.

The Nordic countries are characterised by a well-functioning system of cooperation between the social partners, namely the government, employers' organisations and trade unions.

All Nordic countries have come a relatively long way in the area of gender equality, partly as a result of ambitious family policies. 
market on equal terms. Nordic solutions such as subsidised and quality childcare, generous parental leave schemes for both parents and flexible work arrangements are all rooted in this ambition. The Nordic childcare model has contributed to a dual-breadwinner structure where both parents can work. Most Nordic parents put their young children in childcare. It has become a societal norm to do so, and as a result the share of working women is significantly higher in the Nordic region than the global average. The established system, with subsidised childcare for every child regardless of parental income and the parents' employment statuses, has paved the way for this development.

\section{The Nordic Model}

Descriptions of life in the Nordic countries often involve references to the Nordic model, which is characterised by a political ambition to reduce inequality. All Nordic countries use the tax system to redistribute wealth and reduce economic inequalities. This is inextricably linked to the expansion of social democracy and the idea that citizens should be able to maintain their standard of living in times of sickness, incapacity, unemployment and when having children. The Nordic countries have a well-developed public sector, and the public services and social welfare systems are inclusive and universal. The individual pays relatively little for medical care and education as all citizens engaged in paid work help fund the social welfare system through taxes.
Autonomous labour markets controlled through well-functioning collaboration between the government, employers' organisations and trade unions are a key component of the Nordic model. The Nordic countries are characterised by strong, independent and representative organisations for employers and employees. Trade union membership is more common than in other regions of the world, and as a result of the high membership numbers, the organisations can act independently and negotiate agreements adapted to the conditions in their respective sectors. In addition to legislation, working conditions are regulated sector by sector through collective agreements, establishing the rights and responsibilities of employer and employee in the workplace. Thus, the collective agreements guarantee decent working conditions, employee security and indeed employee productivity in the labour market.

The manner in which the Nordic countries have come relatively far on their path to gender equality is not therefore without a broader context. It is part of a movement since the late 1960s toward social justice, equality and rights. And a big part of this was an ambitious family policy. Nordic family policy has aimed to actively facilitate behaviour change, with an expressed goal of gender equality through increasing women's participation in the labour market, as well as facilitating an increase in men's involvement in the care of their children. In short, Nordic family policy has encouraged a sharing of house-

\section{Nordic challenges}

The Nordic model has undoubtedly increased the share of women participating in the labour market and women's economic independence. However, the labour market remains characterised by a high degree of occupational segregation. The work that has traditionally been carried out by women often unpaid work in the home - is now being undertaken by women in the public sector in the form of childcare, healthcare and eldercare. A large share of Nordic women work part-time - in many cases not by choice - at the same time as they continue to carry out the majority of the unpaid work at home.

Another challenge is that society and the rest of the world have changed since the Nordic model was established. Today, the labour market is characterised by greater mobility, digitalisation and competition from low-wage countries. Publicly subsidised welfare systems and universal solutions for 
hold and child-rearing responsibilities between parents, implying a transition away from the traditional pattern where women are expected to carry out these tasks alone. Efforts to change the traditional and stereotypical gender roles at work and at home, as well as changing people's views of what is masculine and what is feminine, have been an important part of this work.

\section{Key solutions enabling gender equality}

Gender equality in the labour market requires more than just a battery of initiatives aimed at enabling women to engage in paid work. There is also a need for laws and policies facilitating gender equality within workplaces. Since the 1970s, all Nordic countries have established a set of national gender equality goals covering a wide range of areas, including the labour market. The right to equal pay for work of equal value as per the ILO's Equal Remuneration Convention (C100) is enshrined in law, and gender-based discrimination as per ILO's Non-Discrimination Convention (C111) is prohibited. It has also been deemed important to ensure equal distribution of power and influence in the labour market, and to increase the number of women in management positions.

The various interventions and initiatives promoting gender equality are closely linked and interdependent. The availability of childcare allows both parents to be employed. Both parents taking parental leave enables women to return to work sooner, helps to reduce long career interruptions for women, and normalises men taking care of children on their own. Anti-discrimination laws contribute to preventing negative career consequences of parental leave, and proactive initiatives to break men's dominance at the top of workplace hierarchies help to correct imbalances caused by men previously having had better opportunities to work and pursue a career.

The multitude of Nordic solutions for gender equality is also present in the autonomous regions of the Faroe Islands, Greenland and Åland. These countries have similar social protection systems to the five Nordic countries, meaning they are tax-funded and universal, as well as gender equality policy objectives, subsidised childcare and parental leave systems in place. The labour markets in the Faroe Islands, Alland and Greenland diverge from the other Nordic countries' labour markets in significant ways, among other things in terms of size and geographic and demographic conditions. all residents have been challenged by ideas of a more market-oriented system. There is a trend toward insecure jobs, precarious work and a growing number of workers lacking the protections offered by collective agreements. This is increasing differences in people's working conditions, often depending on factors such as age, gender and immigrant background. For instance, migrant women from outside of Europe continue to face real barriers in accessing and entering into the formal Nordic labour market.

The promotion and development of decent working conditions in the Nordic region co-evolved with an expansion of people's access to social benefits. The challenge is to maintain sound working conditions for all workers, even in a rapidly changing world of work, and to continue to stand up for social protection systems as a means of combatting inequality. 


\section{Key milestones for gender equality}

DENMARK

FINLAND

- ICELAND

NORWAY

SWEDEN

Women gain lega right to engage in commerce

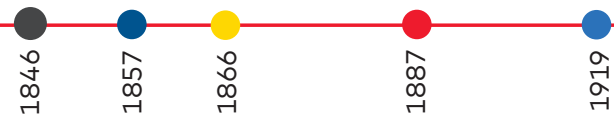

Women gain right to obtain an academic degree

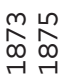

+
$\infty$
$\infty$
+1

덩ㅎํ 윰

Introduction of individual taxation of

incomes earned by husbands and wives

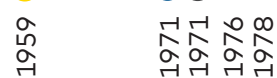

Ratification of the ILO's Convention on

Equal Remuneration for Women and Men

Workers for Work of Equal Value (C100)

Ratification of the ILO's Convention on

Non-Discrimination (Employment and

Occupation) (C111) 


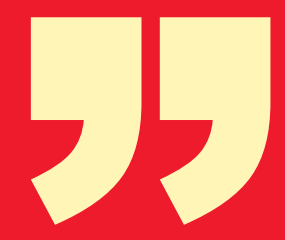

The introduction of individual taxation, in 1971 in Sweden and Denmark, created a strong financial incentive for married women to work. 


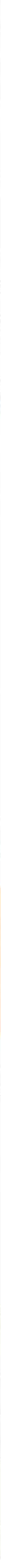




\title{
Subsidised childcare for all
}

\author{
The introduction of quality, affordable childcare is a key reason \\ so many women are in paid employment in the Nordic countries. \\ A distinctive feature of Nordic childcare is that it is available to \\ all children - regardless of family structure, finances and parents' \\ employment. Childcare in the Nordic region is provided by well- \\ trained staff and characterised by highly professional care and \\ learning environments.
}

This brief explains the Nordic approach to childcare and how it stands out internationally.

Most parents of young children find it challenging to combine family life with having a job. As a result, women often put their careers on hold to bring up their children and to do housework. The Nordic countries have made it a priority that parents of small children can participate in the labour market on equal terms. Tax-funded childcare is a central component of this.

One of the targets of SDG5 on gender equality is to 'recognise and value unpaid care and domestic work through the provision of public services, infrastructure and social protection policies and the promotion of shared responsibility within the household and the family as nationally appropriate'. The Nordic countries invest a greater proportion of their Gross Domestic Product (GDP) in childcare services than the world average, and the fees that families pay are relatively low and affordable for every parent. For example, an average Swedish family with small children spends 4.4 per cent of their net income on childcare. The corresponding figures for the United States and the UK are about 26 and 34 per cent. As a result, many couples in the United States and UK find it financially pointless for both parents to work outside the home, and thus the lowest paid parent - usually the mother - stays home for several years.

The issue has been high on the agenda in the Nordic countries. Over 95 per cent of all 3-5-year olds in Denmark, Sweden, Norway and Iceland are enrolled in some form of childcare services (2016). In Finland, the figure is lower. The reason for this is that some of the Nordic countries grant parents a so-called childcare allowance, which enables them, if they so wish, to stay home and take care of their young children themselves. Many Finnish parents choose to take advantage of this option.

Thus, most parents in the Nordic countries see childcare services as a natural part of life. And these countries also have higher rates of working women than anywhere else in the world. Research shows that this is not a coincidence; the Nordic childcare model has contributed to a dual-earner system where both parents are able to both work and take care of their children. While this is an important aspect of achieving SDG5, it also contributes directly towards SDG8 on decent work and economic growth, and to the advancement of the 2030 Agenda's overarching objective of leaving no one behind.

\section{Organisation of childcare services}

Nordic childcare typically involves a wide range of actors. Parents have access to both municipal and private childcare options. The latter type can be either for-profit or non-profit. The educational models on which the childcare services are based vary by country. Family day care, or childcare provided in the home of an often trained childcare professional, is common in Denmark and Finland. In Denmark, this type of childcare is most common for small children 1-3 years old. Family day care 
used to be common in Norway as well, but this has changed as the availability of childcare centres has been substantially expanded.

Regardless of how the childcare is organised, the services must be offered in line with the nationally established early childhood curriculum, by qualified staff and in accordance with particular regulations. One notable feature of the system is that there is a high degree of decentralisation to local authorities when it comes to implementation of national policy. Another is that parents are mainly offered full-time childcare instead of part-time childcare, which in turn facilitates full-time work for parents.

\section{Childcare fees often income-based}

The fees parents have to pay for childcare vary across the Nordic countries. In all countries, however, childcare services are highly subsidised and based on a rights approach - it is a legal requirement that all families be able to afford childcare. In several of the countries, the fees are income-based and parents are offered sibling discounts. For example, in 2015, Norway introduced a new rule capping a family's childcare fee for the first child at six per cent of the family's total income. The other Nordic countries have similar fee caps. In Denmark, the fees may differ slightly between municipalities, but parents never pay more than 25 per cent of the municipality's cost per child in childcare. Norway has a system where children from low-income households are entitled to a certain number of hours of childcare free of charge. From August 2016, this applies for children from 3-5 years of age.

\section{High quality and democratic values}

All early childhood education services are based on the ideals of democracy, equality, cooperation and independence. The ambition is for the childcare centres to help the children become responsible citizens with an awareness and appreciation of democratic principles. The childcare services are organised based on a children's rights perspective, whereby the ambition is to provide all children with equal opportunities regardless of socio-economic background. Childcare services are even characterised by the interplay between care and learning, and by respect for each individual child. Each child is entitled to influence their own life and environment, and it is considered important to involve the children in the planning of activities.

This approach is in line with the UN's Convention on the Rights of the Child (UNCRC), which stresses that all children have the same rights and equal value and may not be discriminated against for any reason. Nordic childcare centres are operated by well-educated pre-school teachers and childcare workers with a high level of professionalism.

\section{Key driver of growth}

Nordic women have higher employment rates than women in most other countries. In fact, 73.5 per cent of women engage in paid work (2018), while the average rate is 67.7 per cent in the EU.

Family-friendly policies like childcare introduced over the past 50 years have increased Nordic women's workforce participation. And it has boosted growth in GDP per capita by 10-20 per cent.

\section{An equal start in life}

All Nordic countries share a central objective, namely that childcare services shall contribute to equal opportunities for all children. Denmark emphasises that childcare services shall contribute to integration and a greater sense of community in society, and Finland that children shall learn to be respectful of cultures and religions that differ from their own. 


\section{Investments in family benefits and childcare}
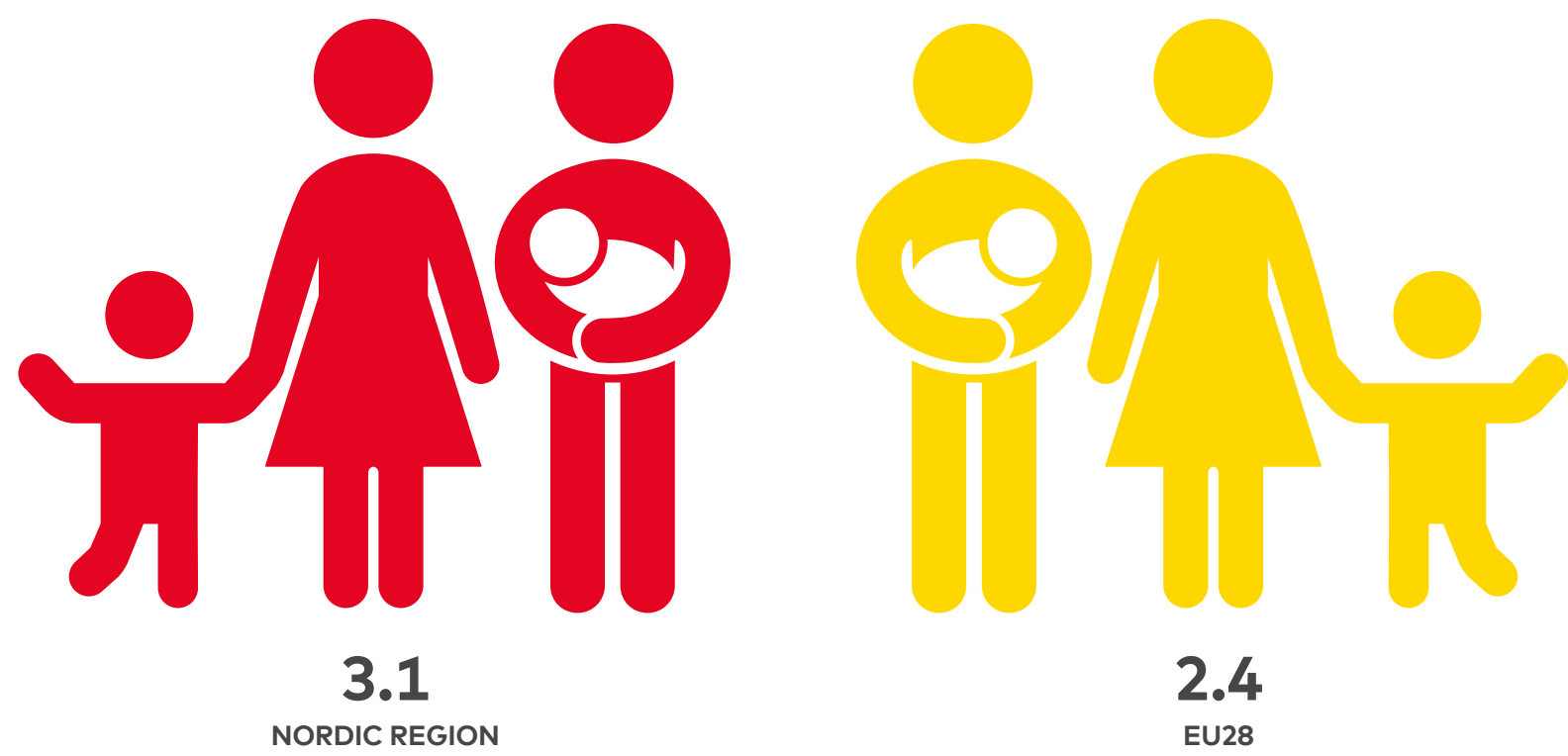

2.4

EU28

\section{D5}

The Nordic countries are characterised by highquality early childhood education. The responsibility to raise children to become democratic citizens lies with not only their families but also society at large.

Sigtona Halrynjo, The Institute for Social Research, Norway 


\section{The right to childcare after parental leave}

Almost all 3-5 year-olds in the Nordic countries are enrolled in some type of childcare services. Even many children aged 0-2 spend time in childcare outside the family. Compared with other OECD (Organisation for Economic Co-operation and Development) countries, the Nordic countries have much higher shares of children 0-2 years of age enrolled in some type of childcare. In Denmark, the figure is reaching over 60 per cent, compared with an OECD average of 33 per cent. This pattern also becomes evident when looking at the money countries spend on childcare services, as the Nordic countries spend more money on childcare for young children than the global average.

There are many reasons for children's early entry into childcare in the Nordic countries. Ultimately, however, it is a result of the persistent political ambition to enable all parents to engage in paid work while raising children. To this end, the governments have ensured a smooth transition between parental leave and childcare. In all Nordic countries except Iceland, parents are entitled to childcare for their children after their parental leave. The timing of children's introduction to childcare is therefore often linked to the duration of the parental leave. Finnish children start childcare later than children in the other Nordic countries. This is because many families use the childcare allowance to bridge the time between parental leave and enrolment in a childcare centre, and a childcare allowance is paid to parents for taking care of their children at home. In Finland, parents are eligible for the allowance until the child is three years old. However, many parents who take care of a small child at home also let older children stay home. A similar benefit is available in Norway, although in Norway there is a trend of letting children enter childcare earlier than in the past. Norwegian childcare services have been dramatically expanded since the right to childcare from age 1 was introduced. Research also points to a change in attitudes among Norwegians, where everybody - regardless of socio-economic background - has become more inclined to the idea of putting their children in childcare.

\section{Nordic challenges}

Although the Nordic countries have come a long way when it comes to solutions for affordable and quality childcare, a sustainable and gender-equal system for early childhood education is still not a reality. The Nordic region therefore wants to invite others to a discussion on how the following challenges can be effectively dealt with.

\section{Staffing levels and quality}

The quality of childcare is often measured in terms of staffing levels, or number of children per teacher in a childcare group. In some Nordic countries, it is a challenge to recruit enough childcare workers to meet the needs of the expanding sector.

Sex-segregation in care

Over 90 per cent of the childcare workers in 


\section{Share of Nordic children enrolled in childcare}

per cent of age group (2016). Source: Nordic Statistics 2019

1-2 years
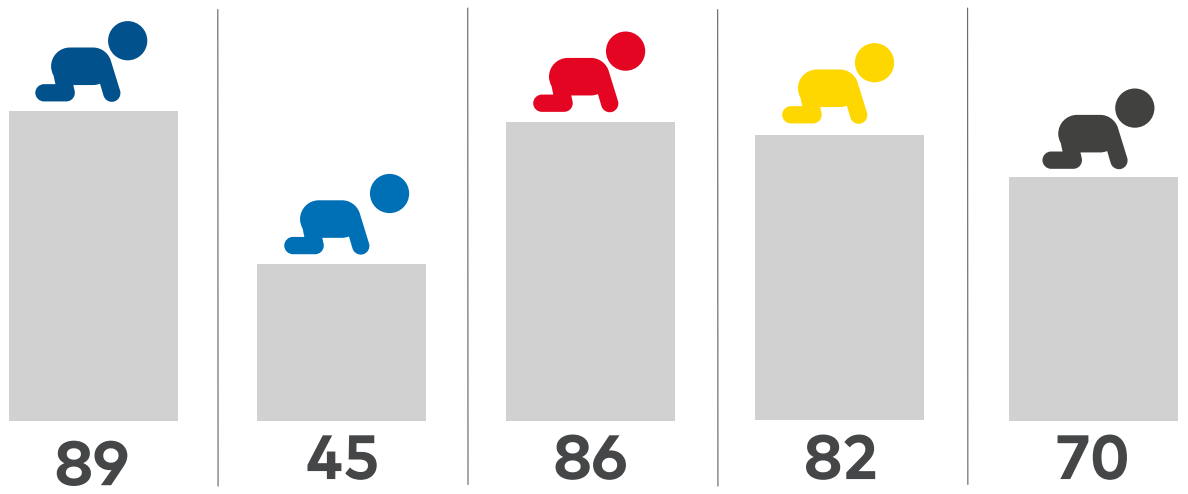

3-5 years
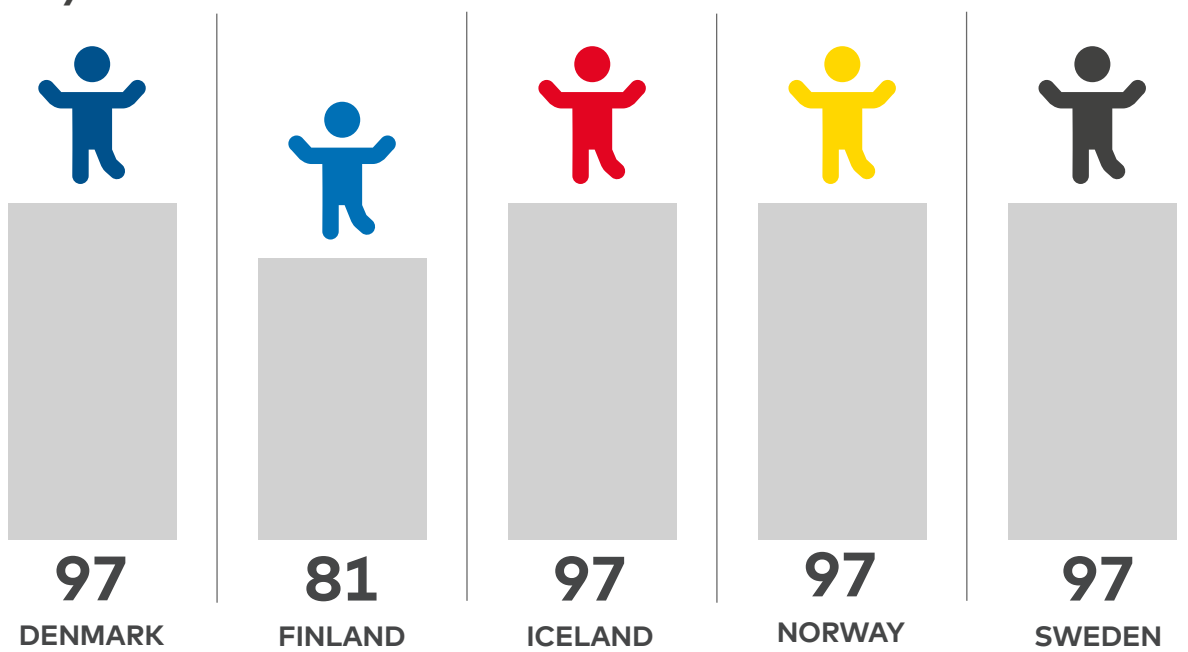

the Nordic countries are women. How can

tal leave. New children need to be enrolled

the gender balance be effectively and throughout the year, but most spots

rapidly improved? become available at the end of the terms.

\section{Availability and access}

Several Nordic countries are facing challenges in meeting the demand for childcare. In particular, there are difficulties making childcare available exactly when parents need it, such as at the end of their paren- 
TRUE STORIES

\section{NORWAY: \\ WHERE ARE THE \\ MEN IN CHILDCARE?}

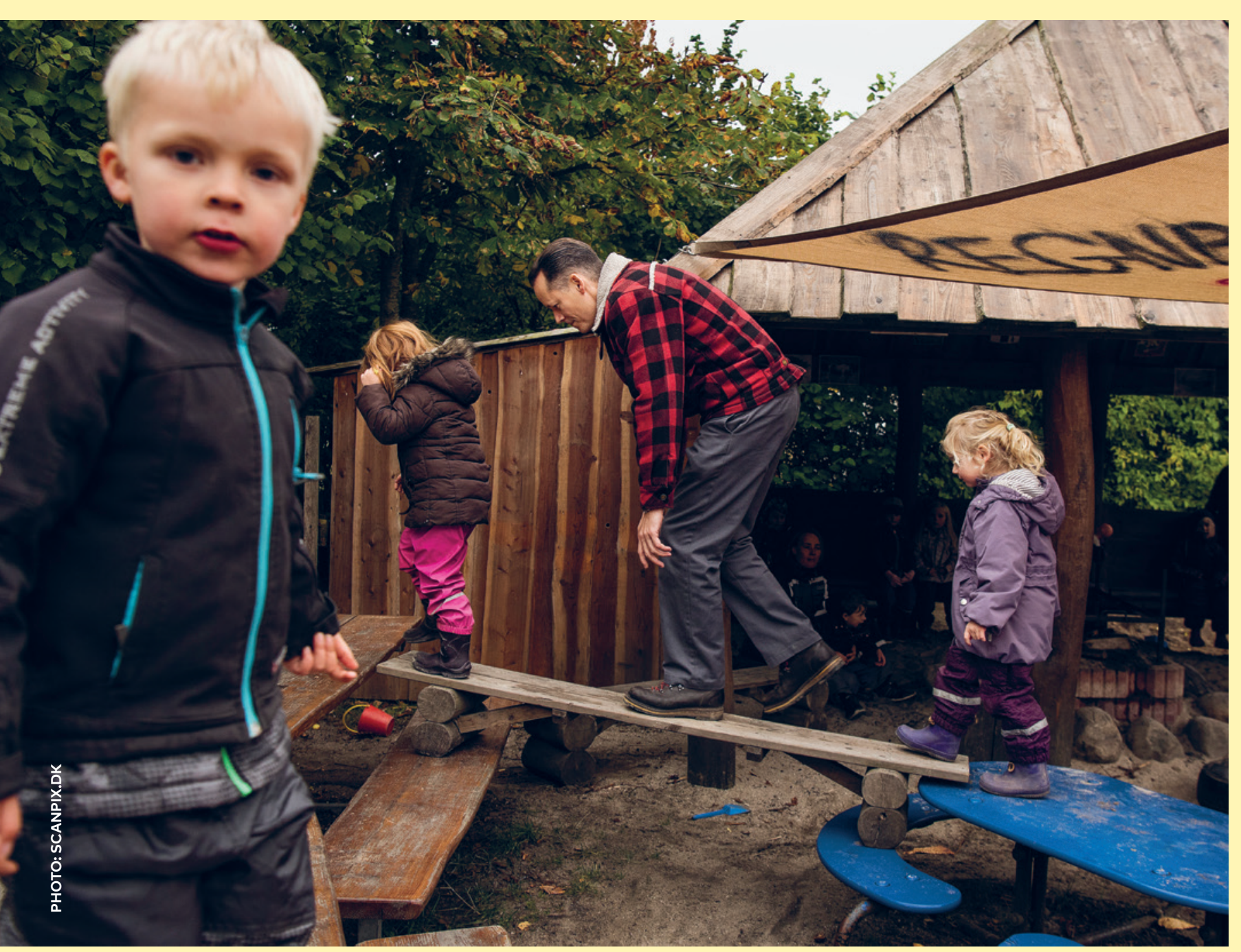




\section{1,700 MEN WORKED IN THE NORWEGIAN CHILDCARE SECTOR in}

1990. In 2009, the number had increased fivefold to 8,400. Since then the level has remained the same, with 7,950 men in 2018. Kanvas, a non-profit childcare provider with 56 childcare centres in Norway, has been particularly successful by achieving a ratio of 20 per cent men and 80 per cent women (2010). Kanvas points to the relatively good gender balance as a sign of high quality.

\section{Several Nordic countries have an ambition to increase the number of male childcare workers. Norway has been more successful than the others.}

Since 1990, the number of men employed in the childcare sector has increased fivefold. At present, more than nine per cent of all childcare workers are men, which is a significantly higher share than in the other Nordic countries.

Norway's success can be attributed to persistent political efforts nationally, regionally and locally. The first national action plan to increase the number of men working in childcare was presented in 1997, and in 1998 it became legal for employers to hire a man instead of a woman in cases of equal, or almost equal, qualifications. From 2000 to 2010, Norwegian childcare services were dramatically expanded, creating a surge in the demand for childcare workers. County administrations developed action plans specifying how more male workers could be recruited, and regional conferences on gender equality and men in childcare were arranged. Special contests were advertised, where childcare operations involving at least 20 per cent male employees were recognised. Special model childcare centres were also appointed and provided resources to advise other centres on how to recruit and retain more men.
The Norwegian campaign has also involved efforts to make more boys interested in a career as a preschool teacher. In many counties, municipalities have the opportunity to invite boys in lower secondary school to work in childcare. The boys are paid for their work. The idea is for the boys to gain a positive experience of childcare and that this ultimately will reduce the prevalence of gendered career choices. Since 2010 the number of municipalities that try to involve boys at the secondary school level to work in childcare has increased.

One goal of Norway's efforts to increase the number of men in childcare is to make the labour market less gender-segregated. A gender balance is considered important for the children, for the work environment and for gender equality. But more than anything, the efforts are meant to change the traditional view of men's gender roles. More men in childcare means more role models showing that men, too, can provide nurturing care.

Source: Nordfjell \& Nielsen 2011 


\section{AN EARLY START TO GENDER EQUALITY}

\section{Several Nordic countries have established that efforts to achieve gender equality must be integrated into all childcare services.}

This means, for example, that all children, regardless of sex, should have the same opportunities and that gender stereotypes must be discouraged. In Sweden, so-called gender-responsive education has been politically prioritised and widely implemented, in particular in childcare. Gender-responsive education is based on the view that gender is a social construct that society continues to reproduce and that it perpetuates inequalities. The aim of the model is to ensure that girls and boys are treated equally and that gendered patterns are not reproduced or reinforced.

In 2002, the Swedish government invested about EUR 1.2 million in gender equality training for childcare workers. The following year, in 2003, a special gender equality commission was appointed and tasked to develop the methods for promoting gender equality in Swedish early childhood education. The goal was for each Swedish municipality to have one gender educator. In 2006, half of all municipalities had a gender educator who among other things focused on childcare services. Since then, the number has decreased. But the initiative is an example of how gender and gender equality issues are addressed in Nordic childcare services.

In all Nordic countries there are laws promoting gender equality in early childhood education. The Norwegian curriculum states that 'equality between the sexes must be reflected in the applied teaching methods' and that 'the staff should reflect on their own attitudes and on society's expectations of boys and girls. The Icelandic curriculum stresses that all children should be trained in equal rights, with an emphasis on preparing boys and girls for equal participation in society, in family life and in the labour market. It is also considered important to point out various grounds for discrimination and how they interact.

Source: Heikkilä 2013 


\section{DENMARK: A TOP INVESTOR}

\section{Denmark spends more money on childcare as a share of GDP than any other Nordic country.}

Danish children also start the earliest in childcare, and almost all families with young children take advantage of the services. Moreover, Denmark was the first Nordic country to implement a reform that paved the way for public childcare in 1964. The decision was based on a need to expand the country's workforce. It became necessary to enable more women to enter the labour market. High-quality childcare for everybody became a prioritised issue, and in the 1980s, most young children in Denmark were enrolled in some type of childcare services. Moreover, the country has a childcare guarantee, which means that all children are entitled to childcare services from when they are around six months old.

Denmark has the highest proportion of young children in childcare in the region; the figures are 97 per cent for 3-5 year olds and 89 per cent for 1-2 year olds (2016). Unique for Denmark is also that children start childcare earlier than in the other Nordic countries; the enrolment rate for 0-1 year olds is 18 per cent. This can partly be attribu- ted to the duration of paid parental leave, but according to Tine Rostgaard, professor at the Danish Centre of Applied Social Science (VIVE), there is also a cultural explanation: In Denmark, the norm is that women return to work after one year.

'The general attitude in Denmark is that early childhood education is very important, it's a way to prepare children for participation in society and make their opportunities more equal regardless of class. Another function of early childhood education that's considered important is that it helps children learn the Danish language,' she says. 


\title{
Shared and paid parental leave
}

\author{
Both mothers and fathers are entitled to paid parental leave in the \\ Nordic countries. In order to promote and facilitate gender equality \\ at home and in the labour market, efforts have been made at the \\ political level to encourage parents to divide the leave time equally. \\ These efforts have yielded results: Nordic fathers take more paren- \\ tal leave than fathers anywhere else in the world.
}

This brief explains how Nordic parental leave schemes are designed and what sets them apart in an international context.

Parental leave enables working parents to stay home and take care of their young children. Traditionally, mothers have stayed home with their children while their spouses have gone to work. The Nordic countries have seen it as important to enable women to provide financially for themselves and their children. Women's empowerment and self-sufficiency has been a priority. Men's involvement in childcare and unpaid work has also been a policy priority, based on the understanding that it is good for children, good for parents and good for society. As such, they have been at the forefront of introducing longer, paid parental leave that can be shared between the parents. Sweden currently offers the longest period of paid parental leave in the Nordic region, 69 weeks per child, and Iceland the shortest, 39 weeks.

At the global level, there is great variation in parents' right to parental leave. Many OECD countries offer shorter parental leave periods than the Nordic countries, and eleven of the thirty-five OECD member states do not guarantee parents paid leave at all. These include the United States, where national law gives mothers the right to 12 weeks of unpaid leave. Although some states and employers provide more generous protections, the lack of universal paid parental leave makes it complicated for many US parents (and parents from other countries with insufficient leave) to combine work and family life.
The Nordic countries encourage both parents to stay home from work with their young children. In recognition of a gender imbalance in the distribution of parental leave, and with the explicit goal of promoting gender equality both at home and in the workplace, the Nordic countries have taken initiatives to increase the rate of paternity leave through campaigns, organisation and quotas.

\section{Organisation and quotas}

In 1974, Sweden became the first country in the world to introduce parental leave that could be split between two parents of a child. Norway followed suit in 1978, Iceland in 1981, Denmark in 1984 and Finland in 1985. However, the initiative had only marginal effects, as mothers continued to take much more parental leave than their male partners.

All Nordic countries except Iceland offer a special paternity leave that fathers can take immediately after the birth of a child to stay home with the newborn baby and the mother. In 1993, Norway took an additional step by earmarking some weeks of the allotted parental leave period for the father - a daddy quota. If the fathers do not use the quota, the family loses the weeks reserved for them. Since then, all Nordic countries have experience with daddy quotas. Research shows that men have responded to the introduction and expansion of the quota by taking more parental leave. The quotas have also influenced people's thoughts and attitudes regarding paternity leave. The daddy quota, as well as the shareable part of 
the leave entitlement, can also be used by the other parent in same-sex couples in several Nordic countries.

\section{Equal sharing}

The Nordic countries promote an equal sharing of parental leave between women and men for several reasons. One reason is fairness, and a belief that mothers and fathers should take equal responsibility for their children, and that children have the right to be with both parents. Gender-equal parenting also contributes towards a more gender-equal participation in the labour market. The fact that women take more parental leave than men can still affect their careers negatively in too many cases. An extended absence from work may reduce a person's status and opportunities in the labour market. Thus, when more men take long-term parental leave, the prospects for gender equality in the labour market increase.

Nordic research shows that men who take longer parental leave also take more responsibility at home. They are more involved in the care of their children, have better relationships with them and do more unpaid housework. Importantly the men spend time caring for the child or children alone, after their partner has returned to work. This establishes a more fundamental sense of shared responsibility between parents. Several initiatives have been taken at the political level to encourage parents to share their parental leave more equally, and the efforts have been successful. Over the past 15 years, men's share of the parental leave has increased in all Nordic countries. Iceland, Norway and Sweden are the OECD countries with the most even distribution of parental leave between men and women. However, the work to reach the goal of equal sharing of parental leave and childcare continues, as mothers in the Nordic region, compared to fathers, still spend much more time tending to their young children.

\section{The rules vary across the countries}

The exact design of the national schemes granting the right to paid parental leave varies across the Nordic countries. All Nordic countries have paid parental leave schemes consisting of three parts. In Iceland three months are reserved for each parent and three months can be divided between them. Iceland has the shortest period in which parental benefit is payable: 39 weeks. In Norway, parents are entitled to 49 weeks of leave, where 15 weeks are reserved for each parent and 16 weeks can be shared. At 480 days Sweden has the longest legally granted parental leave among the Nordic countries. Since 2016, the earmarked leave for each parent has been 13 weeks and the remaining 43 weeks can be divided between the parents. In Denmark, parents have a total of 52 weeks of leave with parental benefits. 18 weeks for mothers only, two weeks for fathers and 32 weeks that can be shared. Finnish parents have 53 weeks of leave, and since 2013, Finnish

\section{How it works}

Parental leave is an umbrella term that refers

to the right of mothers and fathers to take

time off from work to take care of their

children. It consists of three parts. Maternity

leave is reserved for one parent; and paternity

leave for the other. The third part of the

parental leave can be shared between the

parents as they desire. Different countries

allocate different numbers of days to each

part.

\section{Getting dads on board}

To encourage men to take parental leave, all Nordic countries have tried to make their parental leave schemes as flexible as possible, for example by extending the timeframe within which the leave can be taken and enabling parents to divide the leave into several shorter periods for both parents. 
fathers are entitled to nine weeks of paternity leave until the child is two years old that cannot be transferred to the mother. The payment rates for parental benefits range from 70 to 100 per cent, and several countries offer longer leave with further reduced pay.

\section{Level of parental benefits}

The Nordic countries have given high priority to the issue of compensation levels and allocate significantly more public funds to parental leave allowances than the OECD average. How much parental leave people take is related to how much compensation they are entitled to. In all Nordic countries, parents are compensated financially for the income they lose during their parental leave. The compensation can be income-related or a fixed amount. The exact level of income-related compensation varies greatly. Norway and Denmark have the highest level of compensation, and Finland the lowest. All Nordic countries except Finland have put a limit on the compensation that can be paid to a parent. There is an apparent correlation between the level of compensation and the amount of parental leave fathers take; fathers in Iceland, Norway and Sweden, where they enjoy among the highest compensation levels, take more parental leave than fathers in other countries worldwice. Conversely fathers take the least amount of parental leave in countries like Australia, France and South Korea, where compensation levels reach less than half of pre- leave income. The Nordic countries have given high priority to the issue of compensation levels and spend more tax money on parental leave allowances than the OECD average.

\section{Parental leave, attitudes and level of education}

The share of parental leave taken by men varies across the Nordic countries. Iceland tops the list with 30 per cent. Sweden follows closely behind with 29 per cent, and in Norway the figure is 20 per cent. Finnish and Danish men account for 11 per cent of all parental leave outtake.

So, which men are most likely to utilise their right and go on parental leave? While the earmarked paternity leave is taken up by men in all sectors of the labour market, fathers are more likely to go on longer-term parental leave when both parents have high levels of education, or when the father has lower or the same income as the mother. The same is true when the father works in the public sector and the mother works in the private sector. Self-employed men and men in management positions have a relatively low prevalence of going on long-term parental leave.

Research shows that attitudes to paternity leave are becoming increasingly positive among parents, the general population and the social partners in all Nordic countries. Many different actors in the labour market are taking initiatives to encourage men to go on parental leave. For example, some

\section{Importance of paid leave}

South Korea grants the longest periods of non-shareable parental leave in the OECD. Each parent is entitled to one year, and it cannot be transferred to the other parent. However, with a compensation rate of 40 per cent of the parent's pre-leave income (significantly lower than in the Nordic countries), men take very little parental leave. Around 90,000 South Korean workers took parental leave in 2016, but only 8.5 per cent of them were men.

\section{The parental leave effect}

Men who go on long-term parental leave in the Nordic countries are more involved in the care of their children throughout their lives. They do more household work and domestic chores, communicate better with their partners about the needs of their children and have a better understanding of their children and partners' daily life. Studies from all over the world, including Denmark, also show that involved fatherhood improves their health status. 
employers offer employees more weeks of paternity leave and higher compensation levels than required by law. In Denmark, several trade unions have included the right to paternity leave where the respective employers have agreed to pay fathers their full salaries if they choose to take the weeks of parental leave that are reserved for them in collective agreements. At present, around 75 per cent of Danish workers benefit from a collective agreement with a built-in earmarked paternity leave, and the Norwegian trade unions and employer associations are strongly in favour of an expanded daddy quota.

\section{Families outside the norm}

Revising the parental leave schemes to make them more inclusive of non-traditional families is a challenge that remains to be solved across Nordic countries. People in the Nordic countries live in a great variety of family constellations, including lesbian, gay, bisexual, transgender and queer (LGBTQ) families and single-parent households. Parental leave schemes are to some extent adapted to include LGBTQ families. For instance, in Denmark and Norway, a mother's female partner has the same rights to parental leave as a father in a heterosexual couple. However, for the most part, Nordic family benefits systems are built around the notion of heterosexual, nuclear families, and this can have unintended effects on families that do not conform to this norm.
In Sweden, the system is based on the idea that parents are willing and able to cooperate with each other, which may become problematic if they disagree on important issues. In cases of joint custody, each parent is entitled to half of the parental leave. If one of the parents does not want to take the allotted days of parental leave, the remaining days can be transferred to the other parent, but if the days are not transferred and the daddy quota is left unused, eight months of parental leave are automatically cancelled. This in turn means that the total parental leave taken for a child may not be enough to cover the period until the child starts in childcare, which may in turn affect the single parent financially. In Finland, only fathers who live with the child are entitled to parental leave. Thus, the system is not adapted to parents who do not live together.

\section{Nordic challenges}

Although the Nordic countries have come a long way when it comes to paid parental leave for all new parents, several important challenges remain. The Nordic region wants to invite others to a discussion on how these challenges can be effectively dealt with.

\section{Involved fatherhood}

Although the Nordic countries are moving in the right direction, mothers continue to take much more parental leave than fathers. The right to long and flexible periods of parental leave can become a gender equality trap if only women utilise it. How can men be encouraged to take more parental leave and become more involved in the care of children?

\section{Care of parents and other family members} The ability of parents to combine parenthood with a career has been a central aspect of the 


\section{Share of parental leave taken by fathers}

per cent (2017)

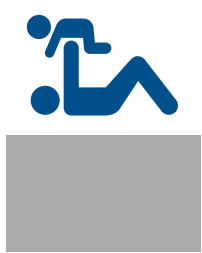

11 DENMARK

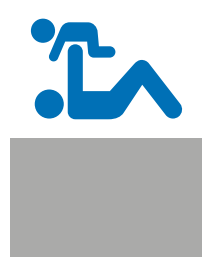

11

FINLAND
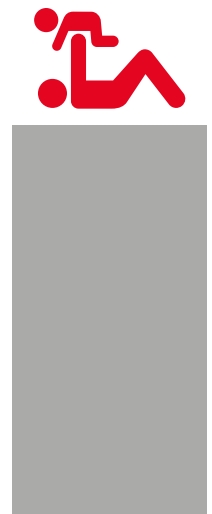

30

ICELAND

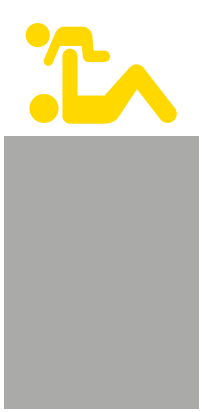

20 NORWAY
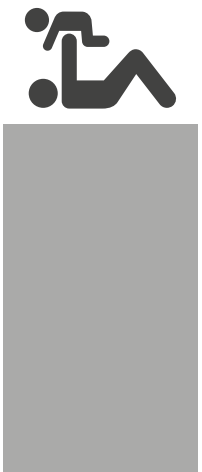

29

SWEDEN

In the Nordic countries, data on gender equality is gathered and evaluated. Access Nordic gender equality indicators here:

norden.org/statistics

Source: Nordic Statistics 2019

Nordic welfare model. One issue that has not received the same attention is that many adults (women in particular) take on the bulk of caring responsibilities for their ageing parents or other family members, in addition to their own children. What are the implications of this dual care role on women's participation in the labour market, particularly in the light an ageing populating and increasingly longer life expectancy?
Make the parental leave equally useful for non-traditional families

People in the Nordic countries live in a great variety of family constellations, including LGBTQ families and single-parent households. What are the unintended effects of current parental leave schemes on families that do not conform to the heterosexual, nuclear norm? 


\section{ICELAND: WORLD'S FIRST TRIPARTITE PARENTAL LEAVE}

\section{In 2000, Iceland became the first country in the world to introduce a parental leave model consisting of three parts.}

In the past, parents had been able to share six months of parental leave, but in practice, almost exclusively women used it. The reform included an extension of the parental leave from six to nine months per child, and of these, three months were reserved for one parent, three for the other parent, and three months to divide as they wished. The initiative had an immediate and powerful effect. Before the reform, less than one per cent of men in Iceland went on parental leave; after the reform, this skyrocketed to 87 per cent. Today, Icelandic fathers take a larger share of all parental leave than in any other Nordic country.

A quantitative study of new parents in Iceland, based on a longitudinal survey carried out in three parts, shows that the reform has had a positive impact on gender equality. The parents were asked how they divide their housework and domestic chores, childcare and income-generating work. The responses show that the division of paid work and domestic chores has become more equal since the new law was introduced, and that fathers who take the parental leave reserved for them become more involved in the care of their children.

Source: NIKK 2016

\section{GLOBAL TECH FIRMS ARE SETTING THE TREND}

\section{Several global technology companies are leading the way by offering their employees paid parental leave.}

One example is Spotify, the Swedish online music service giant, which since 2015 , grants six months paid parental leave to all full-time staff all over the world, including same-sex couples and adoptive parents. In addition to six-month parental leave, Spotify offers one-month flexitime, where parents can work from home. The policy has received a lot of attention in the United States, where Spotify has offices, and where larger private companies are only legally required to offer their women employees a minimum of 12 weeks of unpaid parental leave.

'We strongly believe in the connection between employee well-being and the development of the company. A healthy balance between work and family enables our workers to grow and accomplish great things both at work and at home,' says Katarina Berg, chief HR officer at Spotify.

She argues that Spotify comes from a Swedish tradition where a good work environment, gender equality and opportunities for parents to spend quality time with the most important people in their lives are considered important. Spotify is not the only multinational company that promotes the right to parental leave. In fact, this has become somewhat of a trend among the technology giants in Silicon Valley. Companies such as Microsoft, Facebook, Google and Apple now all offer their workers longer periods of paid parental leave than the statutory minimum, usually as one component of broader gender equality and inclusion HR policies, designed to recruit and retain talented employees from all backgrounds. 


\section{WHAT HAPPENS WHEN THE CHILDREN ARE SICK?}

\author{
Young children and in particular children in \\ childcare tend to get sick often. Consequently, \\ parents often have to stay home from work to \\ take care of a sick child.
}

Parents in all Nordic countries have the right to stay home with a sick child, although the exact rules vary. In Sweden and Norway, the right is protected by law. In the other countries, it is regulated jointly by the trade unions and employer organisations.

In Sweden, parents can stay home for a total of 120 days per child per year until the child turns 12 years old. On these days, they receive 80 per cent of their regular income up to a maximum amount. Norwegian parents are entitled to 10 paid days per year until the child turns 12 years old. A single parent is entitled to 20 days. The compensation rate is 100 per cent of the lost income. In Denmark, the compensation rate and number of days a parent can stay home are regulated through collective agreements, often one to two days. Thus, there is no statutory right of absence in the case of a child's illness with the exception of force majeure cases. Finnish parents may stay home for four days per child if the child is younger than 10 years old, yet some employers voluntarily offer additional paid days off. In Iceland, parents have individual rights to stay home from work to take care of a sick child. However, they do not have a legal right to compensation. Still, many employers pay employees their regular pay when they need to stay home, and the exact rules and number of days are regulated in sector-specific collective agreements.

\section{DENMARK: BANKING ON INVOLVED FATHERS IN THE FINANCE SECTOR}

\author{
In Denmark, the right to parental leave is \\ regulated by law. However, the exact design \\ and details are largely up to the trade unions \\ and employer organisations to decide together.
}

All Danish trade unions have negotiated generous terms of parental leave in their collective agre-ements and continuous efforts are being made to further improve the conditions. The Financial Sector Union is one of the most progressive trade unions in the country, and has negotiated the right to 16 weeks of paid parental leave for fathers. The Financial Sector Union has about 40,000 members, all of whom work in banking and finance. Approx-imately 50 per cent of the members are men. The result of the progressive collective agreement is clear. Since 2006 men's average use of parental leave has increased by 89 per cent in the financial sector in Denmark. In the same period white-collar male workers have on average increased their use of parental leave by 33 per cent, according to The Confederation of Danish Employers (DA). 'Here at the Financial Sector Union, we have made continuous improvements in the area. For example, parents can take the leave either as one long, uninterrupted period or as several shorter periods,' says Linda Faverholm, senior adviser at the Financial Services Union. 

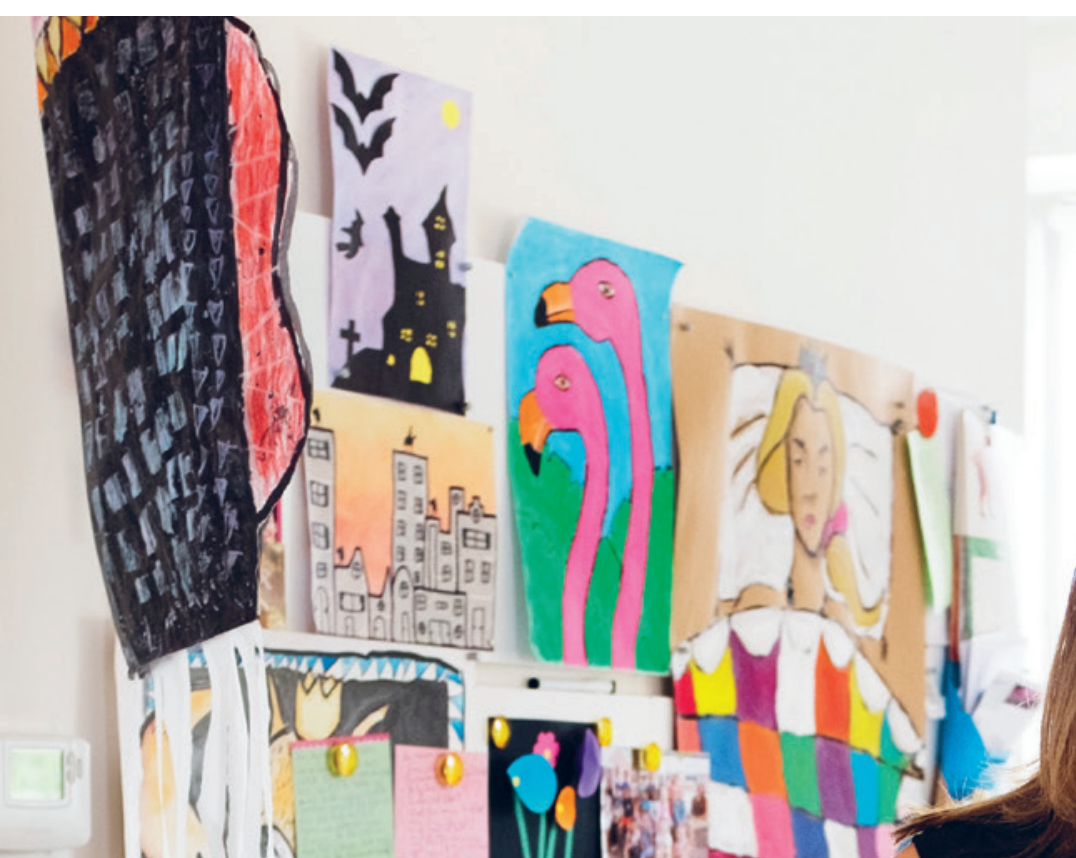

it ment

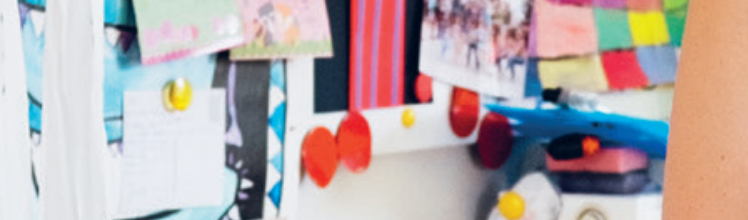
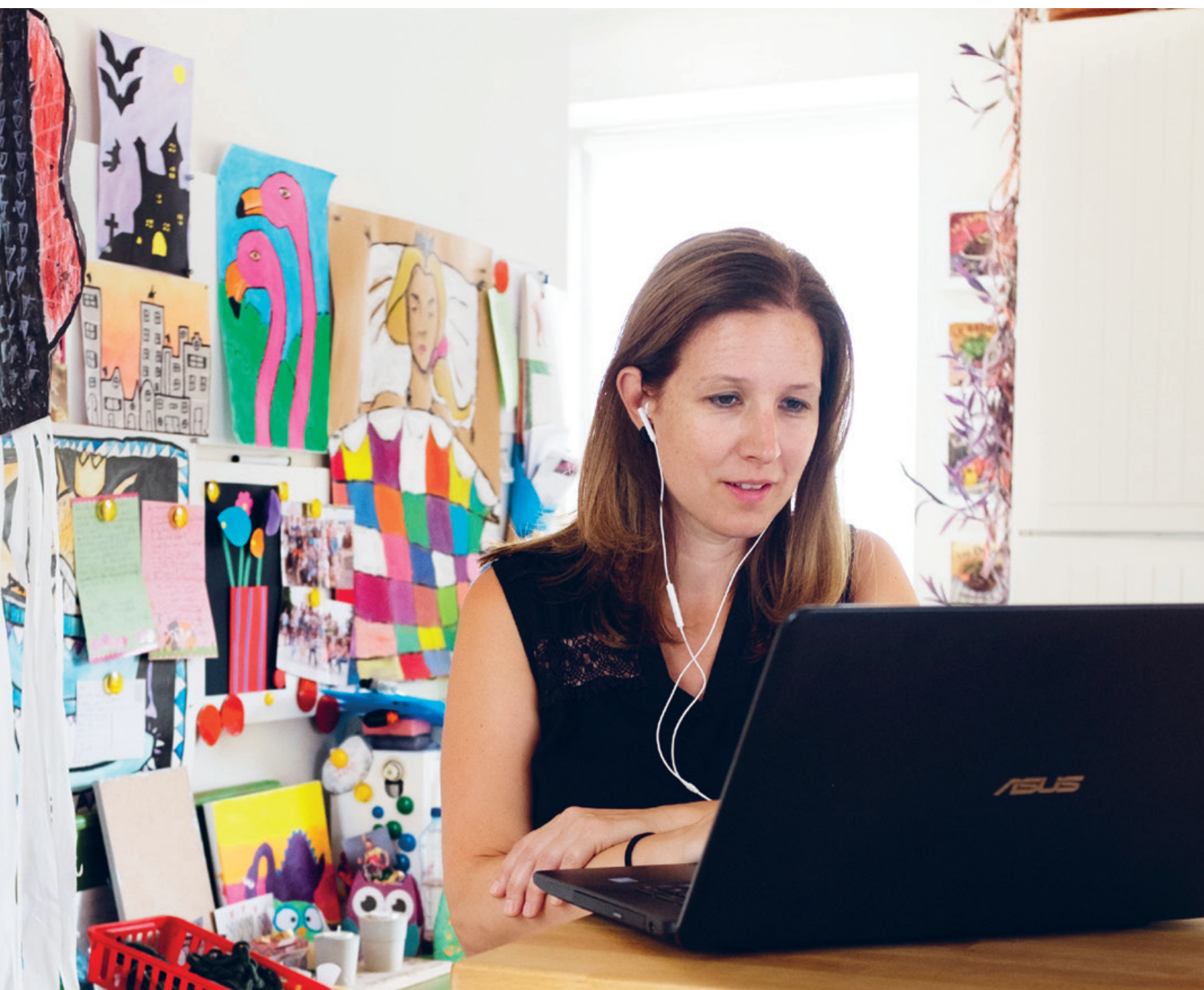

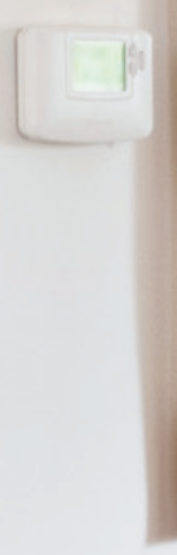

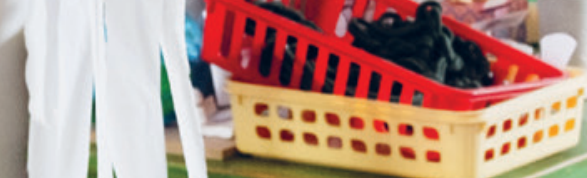

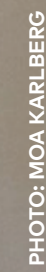

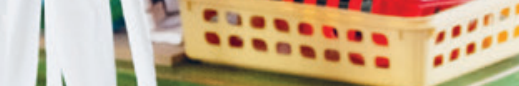




\title{
Flexible work arrangements
}

\author{
Flexible work arrangements enable parents to successfully \\ combine work and family life. The Nordic countries have a strong \\ tradition of collective bargaining, which has resulted in relatively \\ good working conditions, flexible working hours and the right to \\ paid vacation. Nordic companies offer more flexible working hours \\ than anywhere else in Europe.
}

This brief outlines some flexible work arrangements that pertain in the Nordic countries and places them in an international context.

Flexible working hours can make everyday life easier. It enables employees to control the beginning and end of their workdays, and thus make it easier for parents to adapt their work schedules to their children's school and childcare hours, and indeed to look after older relatives. Opportunities to work from home or other remote locations save time and make family life easier, thus enabling better work-life balance.

A European company survey shows that Finland, Denmark and Sweden are leading internationally when it comes to flexible working hours. The results show that more than half of all company employees in Finland, Denmark, Norway and Sweden can control at least some of their working hours. In contrast, 80 per cent of employees in Greece and Portugal report that their working hours are determined entirely by their employers.

The Nordic countries have a long tradition of collective bargaining and a large share of all employees is covered by a collective agreement that ensures decent working conditions. There are often provisions for working hours, vacation, and opportunities for parents to take care of a sick child, which make it easier to reconcile work and family life. Protection of workers' rights and promotion of safe and secure workplaces are prioritised issues in society, which contribute towards sustainable development at large.

\section{Collective agreements and laws}

The Nordic model is characterised by collective agreements negotiated between the trade unions and employers' organisations concerning the rights and responsibilities at work. In the Nordic countries, an employee covered by a collective agreement only needs to negotiate the salary and type of employment contract (such as temporary versus permanent position, or full time versus part time) with the employer when starting a new job. The rules concerning parental leave, vacation, pension benefits and flexible work arrangements have already been decided and will be specified in the relevant collective agreement. A collective bargaining system with strong social partners has been a prerequisite to the ability to build resilient and healthy welfare states in the Nordic region.

It is no coincidence that many employees in the Nordic countries benefit from flexible work arrangements. Rather, it is a result of the Nordic labour market model, with strong organisations representing employers and employees. The Nordic countries stand out internationally with their high rates of union membership, meaning they have the power to establish reasonable sector-specific agreements with the respective employer organisations. Flexible solutions related to job security have been of great importance to the Nordic trade union movement, and unions have continuously emphasised the fundamental importance of equal opportunities for women and men. This, along with persistent political will, has contributed to progressive legislation in this area. 
In addition to the rights laid down in collective agreements, employees in the Nordic countries are legally protected against discrimination in the workplace and the labour market. Progressive and detailed anti-discrimination laws prohibit salary-related discrimination against an employee who is or has been on parental leave. Also, employers are prohibited from asking a person about pregnancy, family plans or marital status during a job interview, nor can they refuse to offer a position to a qualified job applicant for a pregnancy-related reason.

\section{The right to flexible working hours}

A full-time employee in the Nordic countries works for around 40 hours per week, and a large share of employees have some type of flexibility when it comes to their working hours. The exact nature of the flexibility varies depending on the sector and the type of work. Flexible work arrangements may include the ability to work from home or to leave work for a few hours to take one's child to the dentist. Compared with the rest of Europe, people in the Nordic countries are more likely to work from a remote location - an opportunity made possible by the ongoing digitalisation of society.

Besides provisions laid down in collective agreements, the Nordic governments have regulated parents' rights to flexible working hours in law to further help them combine work and family life. In Sweden, employees with children under eight years of age can reduce their weekly working hours by 25 per cent. There is also an option to take part-time parental leave and thus receive partial parental leave benefits. In Finland parents have the right to work part-time. The exact reduction in working hours is subject to negotiation between employers and employees.

In Norway, employees with children under ten years of age have the right to request a part-time work schedule. However, in both Finland and Norway, an employer can deny such a request if there are compelling business reasons. In Denmark, parents are not legally entitled to flexible work arrangements, but may request such arrangements after returning from parental leave without being disadvantaged at work. In Iceland, employers are legally required to take necessary measures to help employees combine work and family life. However, parents are not entitled to part-time work; instead, such arrangements are subject to negotiation between the employer and the employee. One consequence of this is that many Icelandic women work in the public sector, where it is easier to get a request for part-time work approved.

\section{More work part-time}

Many parents in the Nordic countries work part-time. It is particularly common among women. In fact, about one-third of women in the labour force in the Nordic countries work part-

\section{Family-friendly at work}

In Sweden, parents can use their parental leave benefits to shorten their working hours. For example, they can choose to work fewer hours per day and/or take one or a few days off every week the system is very flexible.

Compared with the European average, people in the Nordic countries (and in particular parents) are twice as likely to work from home. 


\begin{abstract}
ALL NORDIC COUNTRIES HAVE LAWS AGAINST DISCRIMINATION AT WORK. The legislation is founded in the ILO's Non-Discrimination Convention (C 111), ratified by all five countries, and, for Denmark, Sweden and Finland, upon EU directives, meaning that discrimination in employment and occupation is prohibited. An employee who has experienced discrimination can report the violation to a government agency. The exact design of the protections available and the structure and powers of government bodies overseeing discrimination issues vary across the countries. In several Nordic countries, employers are required to be proactive in promoting gender equality and equal treatment in order to prevent discrimination.
\end{abstract}

\title{
Nordic equality and anti-discrimination authorities
}

Denmark: humanrights.dk / ligebehandlingsnaevnet.dk

Faroe Islands: javnstoda.fo

Finland: tasaarvo.fi / syrjinta.fi

Greenland: nali.gl

Iceland: jafnretti.is

Norway: Ido.no

Sweden: do.se

Åland: ombudsman.ax/diskrimineringsombudsman

Source: Equinet 2017 
time, except in Finland, where it is just one in five. Women in Aland and the Faroe Islands are more likely to work part-time than most other women in Europe. One reason part-time work has become so common in the Nordic region goes back to the expansion of the welfare state in the 1960s. The occupations dominated by women are found mainly in the public sector, and since women have traditionally taken a greater responsibility for children and household chores, jobs in this sector were designed accordingly. Before childcare services became widely available, part-time work was often the only realistic option for women who wanted to enter the labour market.

\section{Work flexibility increases with education}

Studies show that there is a strong link between an employee's level of education and access to flexible work arrangements. Workers with a university degree tend to have greater control over their working hours and are more likely to occasionally work from home. However work flexibility does not always benefit employees and the effect on gender equality can be ambiguous. Nordic research shows that the trend towards increased flexibility and digitalisation in the workplace can make it harder for the individual worker to draw a distinct line between work-life and home-life, a fact compounded by for example the advance of technology whereby work emails can be accessed anywhere at any time.
Employees with care responsibilities at home may find this particularly challenging.

Women continue to spend more time than men on unpaid household and care work in the Nordic countries. This affects the utilisation of flexible work arrangements. Although both parents have the right to reduce their working hours to take care of their children and families, it is mainly women that work part-time. This often affects their careers and position in society. Part-time work may also have consequences for women's finances, including lower pension savings after retiring. Many part-time working women also say it is difficult to find a full-time job. In some sectors dominated by women, part-time rather than full-time work has become the norm. The likelihood of involuntary part-time work is particularly high for women, less educated workers and foreign-born individuals in the Nordic region.

\section{Nordic challenges}

The Nordic countries have come a long way when it comes to flexible work arrangements, yet several important challenges remain. The Nordic region wants to invite others to a discussion on how they can be effectively dealt with.

\section{Sustainable work-life balance}

Workplaces are becoming increasingly fast paced and stressful. The opportunity to work from home or other remote locations does not automatically mean that people work less. How should we achieve a sustainable work-life balance?

\section{Good working conditions}

There is an increasing number of workers, in the Nordic countries and globally holding precarious jobs or who are not covered by collective agreements or flexible work 


\section{Share of women in work}

per cent (2016)

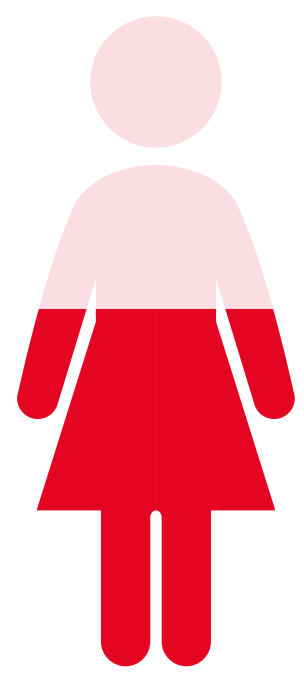

55

50 YEARS AGO

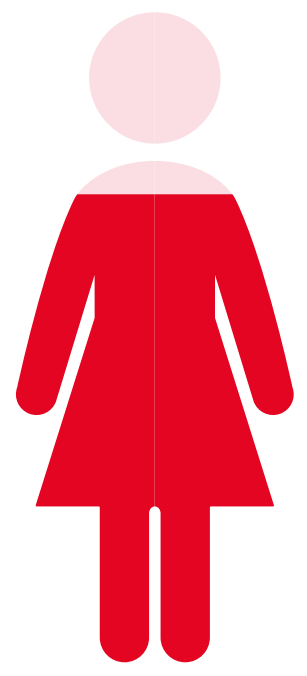

72

TODAY

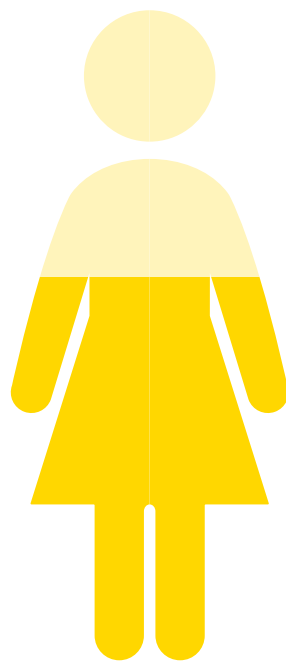

59

OECD AVERAGE TODAY

Over the past 50 years, the employment rate for women has increased from 55 per cent to 72 per cent. The increase in Nordic women's employment rate can account for 10-20 per cent of annual GDP per capita growth.

Source: OECD 2018

arrangements. There is often a pattern in terms of who holds these jobs, such as age, gender and immigrant background. How can we ensure an inclusive labour market with good working conditions for everybody?

Flexibility and gender equality

Flexible work arrangements do not automatically translate into increased gender equality at home, particularly where share of domestic work is concerned. Studies show that women continue to spend more time than men on unpaid housework. How can the work flexibility be arranged so that it helps improve gender equality both at home and in the labour market? 
TRUE STORIES

\section{FINLAND: TECH FIRM MAKES FAMILY-FRIENDLINESS A TOP PRIORITY}

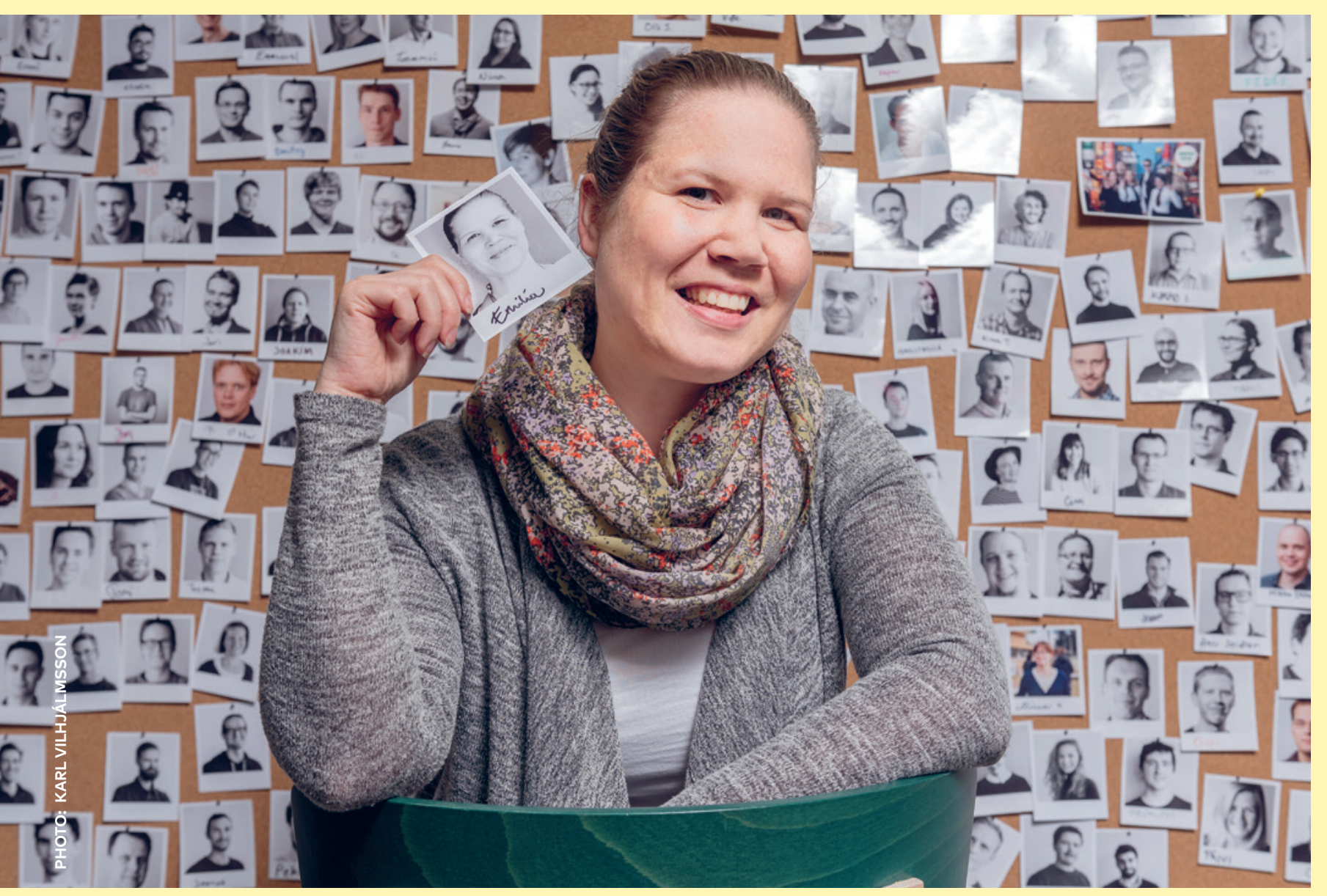

$\uparrow$ Emilia Kyllönen, HR specialist at Futurice 
Finnish technology company Futurice is a world leader when it comes to flexible work arrangements and family-friendly staff policies.

The company has around 300 employees in Finland and over 400 worldwide, of whom 80 per cent are men. Many of them are parents of young children.

'Our employees have flexible working hours as long as they get their work done. If they want to, they can work harder during certain periods and then take some time off,' says Emilia Kyllönen, HR specialist at Futurice.

At Futurice, the staff keep track of and report how much and when they work. However, to keep workers from risking their health and wellbeing, there are some restrictions as to the time of day and number of hours they can work.

Futurice offers vast opportunities for part-time work, regardless of sex, as well as special benefits in connection with parental leave. All fathers receive full pay when they take three weeks' parental leave, which is a more generous policy than that stipulated by the collective agreement for the Finnish IT sector.

'Almost all fathers take advantage of this opportunity and take these weeks off. Many of them also take longer periods of parental leave,' says Kyllönen. The company offers parent workers time off to take care of a sick child. Parents can also use a babysitter service paid for by the firm if they need someone to take care of a sick child while they work. During school breaks, parents can bring their children to work, where children's activities are organised when needed.

'We have for example had a coding camp, where an instructor taught the kids basic computer coding.'

To evaluate the efforts and the company's family-friendly practices, Futurice conducts a survey on a regular basis. A special feature of the questionnaire is that their employees' partners also have been asked to respond at times.

'We ask them how well they are able to combine work and family life and what else the company can do to help,' says Kyllönen.

Futurice has fewer staff sick days than the average in Finland. Kyllönen connects this to the company's flexible work arrangements.

'We think it's important to take care of the staff. We believe that the good things we do will come back to the company, that's why we do it,' she says. . 


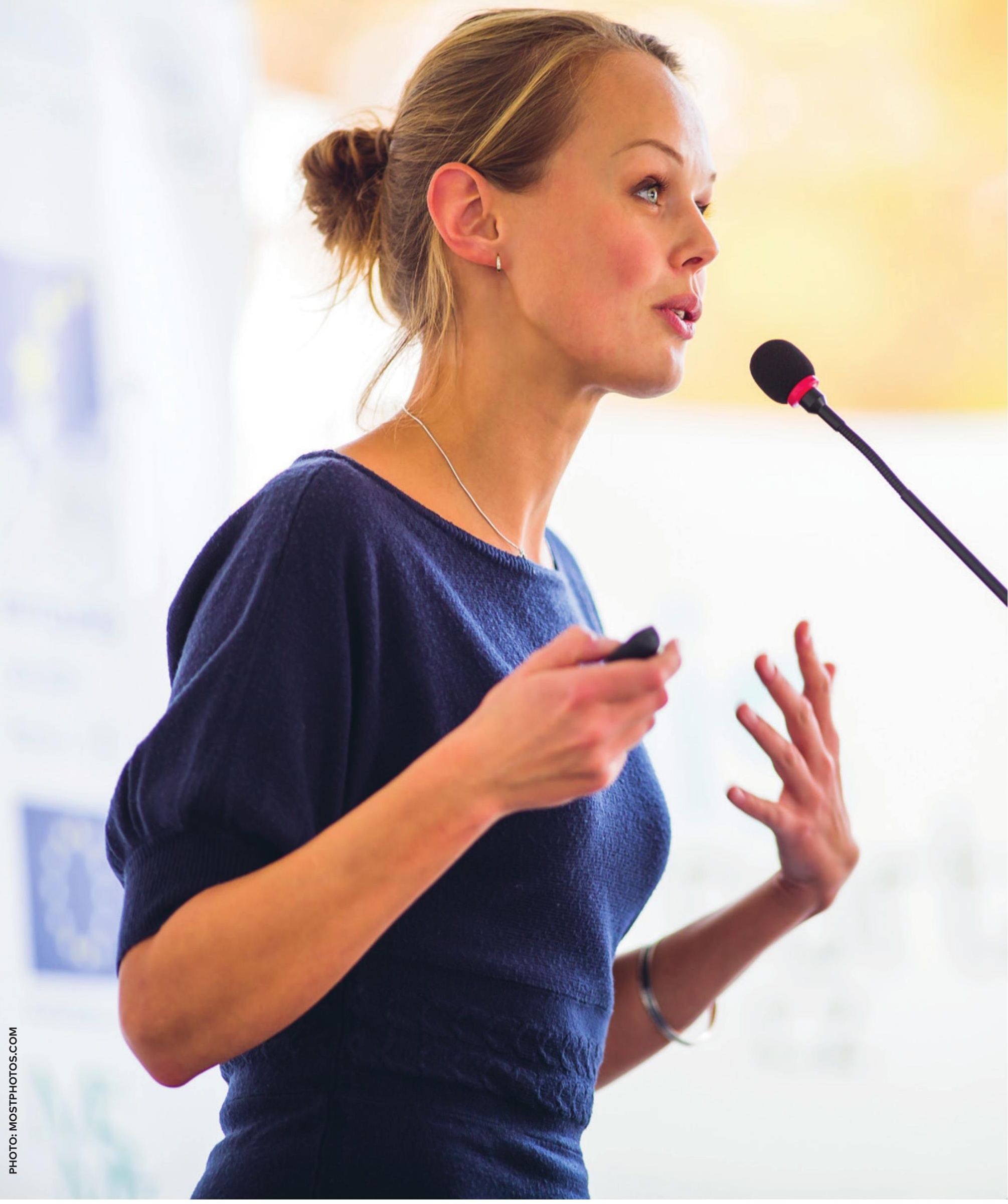




\title{
Leadership and equal opportunities at work
}

\author{
Equal opportunities in the workplace have been high on the \\ Nordic political agenda since the 1970s. Many initiatives have \\ been launched to ensure women and men's equal opportunities \\ at work and for leadership at all levels. Today the Nordic region \\ stands tall in international rankings on gender equality at work.
}

This brief explains what the Nordic countries have done and continue to do to create equal opportunities for women and men at work as well as opportunities for women to advance to leadership positions.

The Nordic countries have long encouraged women's entry into the workforce and striven for a labour market in which women and men can participate on equal terms. All Nordic countries have official gender equality targets, which include specific targets related to the labour market. Men and women have the right to pursue the same jobs and occupations, and it is illegal to discriminate against people because of their sex or gender identity. Nevertheless, women and men continue to face different conditions and perform different work tasks in different sectors, in different positions and with different pay.

\section{Laws and countervailing measures}

As early as 1921, Denmark adopted a law on equal access to employment for men and women, and by the 1970s, the issue of gender equality began to feature on the Nordic political agendas in earnest as all five countries gradually adopted laws and promoted policies to ensure equal opportunities for women and men at work.

Today, all Nordic countries have laws mandating equal pay for work of equal value, as defined by the ILO's Equal Pay Convention (C100). There is also extensive legal protection against discrimina- tion in workplace. For example, it is illegal to dismiss a woman because she is pregnant or has given birth. Both parents are protected from dismissal because they have made use of or wish to make use of their right to maternity, paternity or parental leave. Sexual harassment is also legally prohibited, both in the workplace and in society at large. In addition, in several Nordic countries, employers are required to actively promote gender equality and equal treatment to prevent discrimination. The details of the regulations vary somewhat across the countries, however.

In Sweden, employers are required to both prevent discrimination and be proactive in promoting equality. They must for example develop guidelines to prevent sexual harassment and carry out annual salary assessments. In the salary assessments, an employer may examine salary criteria or bonus schemes to ensure that no one is disadvantaged due to their sex. Employers must also analyse the causes of any discrimination that is unveiled and then take appropriate action.

Icelandic legislation stipulates that employers must take particular measures to protect employees from sexual harassment in the workplace. Finland requires employers to encourage both women and men to apply for vacant positions. For example, an employer may write in a job advertisement that persons of the underrepresented sex are particularly encouraged to apply. According to Finnish law, employers should create 
working conditions that are appropriate for both women and men, and ensure that staff facilities are equally useful regardless of gender and needs.

\section{Iceland legislating against gender pay gap}

Just like in the rest of the world, women in the Nordic countries earn less than their male counterparts. Nordic labour markets are characterised by high rates of women's employment, but also by high rates of occupational segregation. And jobs in the sectors employing a majority of women, such as the education and care sectors, tend to be low paid, whereas those sectors dominated by men are often highly paid. Thus, it is to some extent the high rates of women's labour force participation predominantly in the public sector that has led to the relatively large gender pay gaps. In contrast countries with low levels of women's labour force participation tend to have a small gender pay gap, as the minority of women who do work tend to be more equally spread across the sectors of the economy.

Various efforts have been made to reduce the gender pay gap, without much effect. However, the Icelandic government, in consultation with trade unions and employers' organisations, broke new ground by developing an equal pay standard and adopting it into a new law. The new law, which came into effect 1st January 2018, requires all employers, public as well as private, with at least 25 employees to annually certify their salary structures according to the equal pay standard. The law is introduced in stages over a 3-year period. The goal is to eliminate the pay gap between women and men by 2022 . It stipulates that employers must identify the work tasks a position entails and assign a value accordingly. The underlying idea is that salaries should be determined based on position and not the person holding it, and thus the risk for salary discrimination is reduced. The law also makes the setting of salaries clearer and more transparent. As with other standards, the Icelandic equal pay standard has been developed so that it can be replicated elsewhere.

\section{Women in leadership positions}

The Nordic countries have been proactive in promoting the equal representation of women and men in positions of power. Iceland stands out historically when it comes to choosing women for the highest political positions. Vigdís Finnbogadóttir became Iceland's president in 1980 and held the position for 16 years. She was then the world's first democratically elected female head of state. Today, all the Nordic countries have much higher proportions of female members of parliament than the international average. At present, Norway, Iceland and Åland have female prime ministers, while Denmark, Finland and Greenland have had female prime ministers (and Finland and Iceland women presidents) in the past. The Nordic countries have also actively promoted female representation at the highest

\title{
Mainstreaming as a tool
}

\section{Highly educated women}

\author{
All Nordic countries use gender mainstrea- \\ ming as a strategy to achieve nationally \\ declared gender equality goals. Gender \\ mainstreaming is a way to plan the work in \\ an organisation so that no decision is ever \\ made without first considering how it will \\ affect the balance of power between \\ women and men.
}




\section{Unadjusted gender pay gap}

per cent (2017)

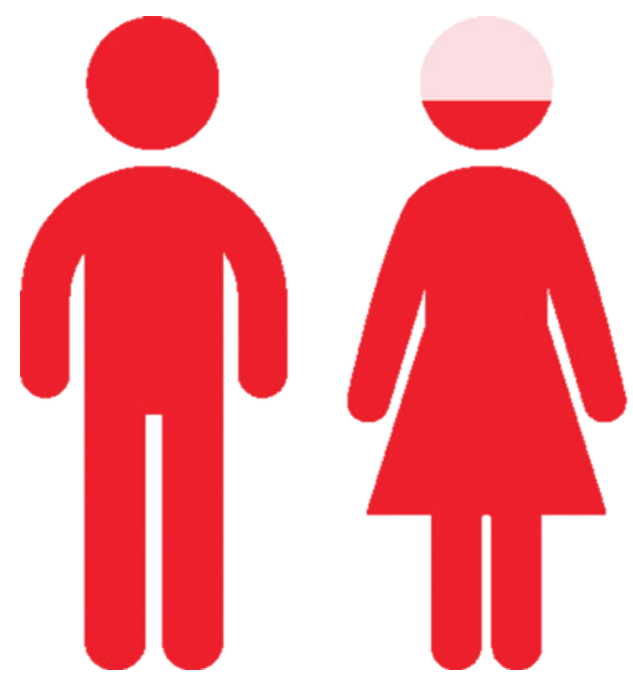

14.3

NORDIC REGION

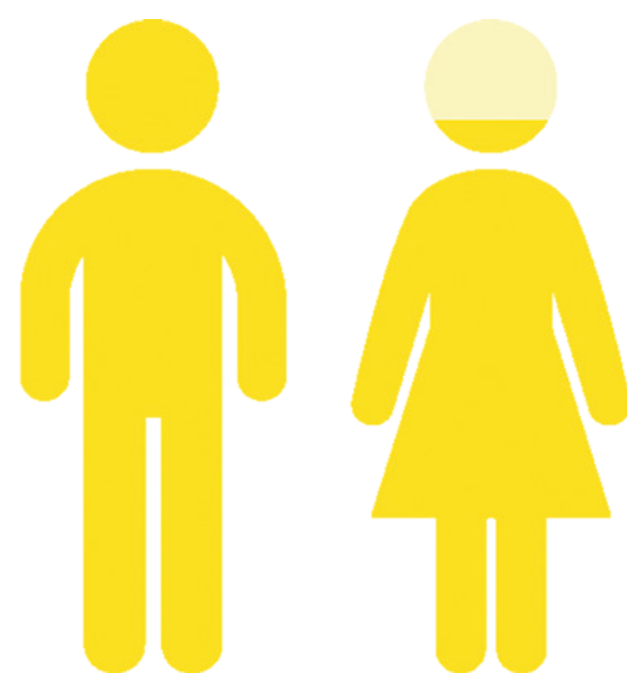

16.0

EU28

In the Nordic countries, data on gender equality is gathered and evaluated. Access Nordic gender equality indicators here:

norden.org/statistics

Source: Nordic Statistics 2019

97

As CEO, you can really make a difference when it comes to gender equality. I believe that all company boards should demand gender equality from their CEOs, just like they demand results in the form of balanced budgets

Bjarni Bjarnason, CEO of Reykjavik Energy. 
decision-making levels, such as on company boards of both public and private enterprises. Similar initiatives have also been taken in the autonomous Nordic areas. Greenland has special rules regarding equal representation of women and men when appointing members to public committees or to the boards of state-owned companies. When the government appoints board members, they must ensure an even gender distribution. As a result, state-owned Greenlandic companies have more women than men on their boards.

Norway was the first country in the world to introduce a gender parity quota law for company boards. According to the law, which came into force in 2008, all company boards must consist of at least 40 per cent women. Several effects have already been observed. When the law was enacted, only around six per cent of company board members were women; today, the share is over 40 per cent. Moreover, the appointment of board members has become more transparent and clearly structured, and the attitudes to gender balance have become more positive in corporate circles. The Norwegian quota law has also contributed to the initiation of a European debate on the male dominance of company boards, and indeed more generally in the business community. Several countries have been inspired by the Norwegian model. By 2016, eight OECD countries had adopted similar quota laws for the boards of listed and/or state-owned companies: Belgium, France, Greece, Iceland, Israel, Italy,
Germany and Austria.

\section{Still few women at the top}

Despite ongoing efforts, a troubling pattern remains: the higher up the hierarchy you look, the more men you will see. This is particularly true in the private sector. Research from Norway shows that the lack of women in leadership positions in the private sector can be linked to the uneven distribution of parental leave and childcare responsibilities at home. Family policy interventions may be necessary and desirable, but as long as women take advantage of them in significantly greater numbers than men, they can become a gender inequality trap.

Studies of the Norwegian quota law show that the improved gender balance on company boards has not spread to top management. The same trend can be seen in Iceland. However, Norwegian authorities have given priority to monitoring the gender balance at the top management levels through the development of CORE - Norwegian Gender Balance Scorecard, which maps the gender balance of the executive committees of the 100 and 200 largest companies in Norway over time. In 2017 there were 20 per cent women in top management positions in Norway's 200 largest companies and 28 per cent women on corporate boards. Eighty-six of these companies were covered by the board quota legislation.

\section{Nordic challenges}

The Nordic countries have come a long way in ensuring equal opportunities in the workplace as well as in promoting women's leadership, yet several important challenges remain. We want to invite others to a discussion on how they can be effectively dealt with.

\section{Differences in pay}

The gender pay gap in the Nordic countries remains stubbornly consistent, despite the fact that the countries have come a long way in a global context when it comes to gender equality in the workplace.

\section{Distribution of unpaid housework}

Women in the Nordic countries spend considerably more time than men on unpaid housework, childrearing and elder-care. Research shows that it is easier for women to pursue a career when there is a more 
The male dominance at the top levels of businesses and other organisations gives men greater access to power and privilege. It also gives them more influence over how workplaces and the entire labour market are organised, which has implications for women's and men's opportunities for advancement, salaries, health and life at large. In Sweden, more women than men hold management positions in the public sector, and vice versa in the private sector. However, compared with their male counterparts in the private sector, research shows that female managers in the public sector have higher levels of education and more responsibility. They also have lower pay, despite being in charge of significantly more people.

gender-equal division of household chores.

How can men be persuaded to do more unpaid work at home?

\section{The limitations of quota rules}

Studies of the Norwegian quota law show that the improved gender balance seen in company boards has not spread to more women CEOs or other managers. One reason for this is that the business world is characte- rised by a wide range of leadership standards and traits that are typically (perhaps stereotypically) associated with men. How can we foster an environment where both women and men can hold top management positions? 
TRUE STORIES

\section{ICELAND: ENERGY COMPANY WALKS THE TALK ON GENDER EQUALITY}

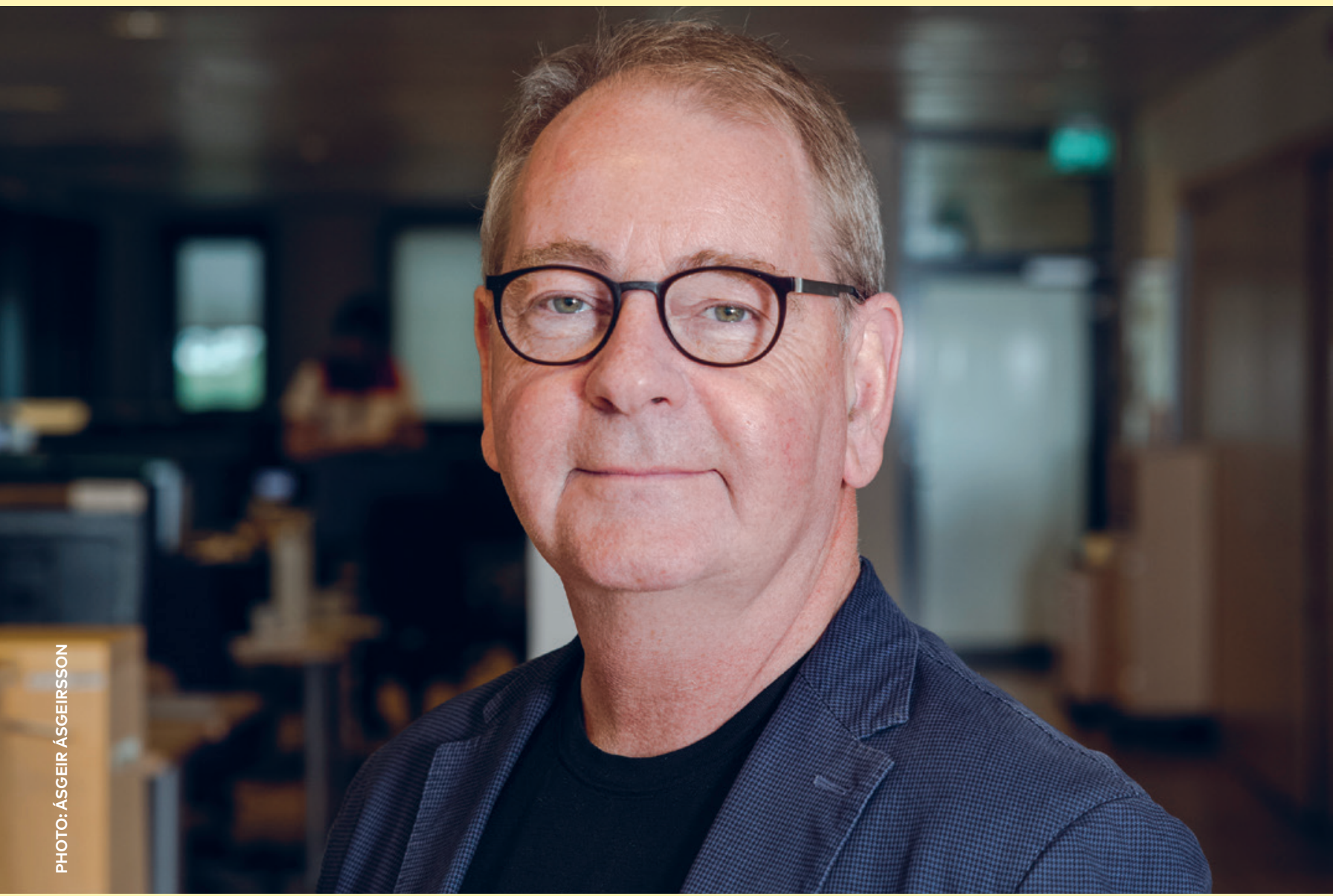

$\uparrow \quad$ Bjarni Bjarnason, CEO of Reykjavik Energy 


\section{Reykjavik Energy has received two major gender equality awards for its efforts, and the staff are proud of their workplace.}

Iceland's municipally owned energy company Reykjavik Energy is over 100 years old. It provides two-thirds of the island nation with drinking water, heating, electricity, wastewater management and other services. When Bjarni Bjarnason, CEO, took over the company in 2011, it was run-down and had a poor reputation. Seventy-five per cent of the managers were men and there were large gender differences in salaries. Bjarnason decided early to create a gender-equal company. Today, 54 per cent of the management staff are women and the gender pay gap has been almost eliminated. In 2019, the gender pay gap was 0.5 per cent in favor of men. Reykjavik Energy measures the gap monthly to keep it within 1 per cent in either direction. The company, which used to be on the brink of bankruptcy, has become an attractive and admired employer.

'The first thing was easy to fix, since the company already had plenty of highly skilled women. As for the differences in pay, a team of external experts developed a tool that helped us identify and correct unfair salaries,' says Bjarnason.

Reykjavik Energy was a traditionally male-dominated workplace. To review structures and the work environment, a gender equality expert was asked to analyse the company. This person looked at everything from the company jargon to the paintings on the walls. The work was supplemented with an annual staff survey aimed at assessing the occurrence of sexual harassment and bullying.

'We measure and take action accordingly. \#MeToo was a wake-up call for many. Reykjavik Energy responded by holding mandatory workshops for all employees on sexual harassment and how to eliminate it. The movement led to changes in labor regulations in Iceland, which led to changes in our procedures,' says Bjarnason.

The company has also taken the initiative to break the male dominance in the energy sector by starting a stand-alone course for upper-secondary students. The course is held at the energy company and half of the participants are girls.

'The students get to try all sorts of things, like working in the power stations. It's great to see an old welder teach a group of 16-year-old girls. The course has led to more girls studying to become electricians,' says Bjarnason.

According to him, the gender equality initiative has had enormously positive effects. 


\section{FINLAND: CONGRATS, YOU HAVE AN ALL-MALE PANEL!}

\section{The Finnish initiative 'Congrats, you have an all-male panel!' has become a viral success. People from around the world submit their contribution to the Tumblr page, which gath- ers examples of expert panels consisting of onlymen.}

The person behind the Tumblr account is Saara Särmä, Doctor in political science at the University of Tampere.

'I saw it everywhere in academia. The more serious the topic, the more men. At the same time, I worked with a large number of highly knowledgeable women who are not part of the panels. It led me to take action,' says Särmä.

People are invited to submit their own examples of all-male panels to the Tumblr page. The posts are complemented with a picture of Baywatch star David Hasselhoff giving a thumbs-up. The account currently has 2,000 posts and about 150,000 views.

'I think the humour made my Tumblr page go viral. It makes it easier for people to take in the message than if I would have been angry and critical,' says Särmä.

She has received a broadly positive response, including from men, many of whom have contacted her and said they appreciate the initiative. They have told her that they have never thought about this and that they have started to decline offers to serve on expert panels to make room for more women,' she says.

Särmä receives contributions from around the world, including Australia, Europe, Latin America and the United States. She says that a similar website has been launched in Latin America, and there is also a new 'good panel' initiative in Europe, which gathers positive examples of what a good, balanced panel may look like.

'Those who organise events need to start thinking outside the box and focus more on diversity and gender equality when it comes to representation. We need to get away from the male stereotype, or else we will only use half of the resources that the population has to offer', says Särmä. 


\section{SWEDEN: CONFRONTING MACHO CULTURE IN CONSTRUCTION}

The construction industry is one of Sweden's least gender-equal occupational sectors. Of 100 construction workers, 99 are men.

The problems include outdated attitudes and sexist jargon. The Stop the Macho Culture campaign was launched in 2015 by Byggcheferna, the Swedish association of construction managers, and the Swedish Building Workers' Union.

'The campaign is still very important in 2019. Our material has become a huge success and other male-dominated industries, such as the Swedish Armed Forces and police, have reached out to us wanting to know how we have gone about it', says Kajsa Hessel, chair of Byggcheferna.

It all began with a survey of women managers in the construction industry. Eighty per cent responded that their workplaces are characterised by a traditional male locker room culture and that they are not treated the same as men. Fifty per cent had experienced sexual harassment either in person or by watching a colleague be targeted. Many respondents said that both men and women are leaving the industry because of the macho culture. The goal of the campaign is to stop the trend, and create a construction industry where everybody is treated fairly.

The campaign's first step was to launch posters and films where children read out loud real-life sexist quotes from the industry. The campaign received a lot of attention, and the film has attracted more than 500,000 views and is used today as workplace introduction for new employees at the major construction companies. The following step was a workshop tour across Sweden, where over 1,000 people from various construction sites gathered to discuss macho culture. A manual and a toolbox were developed, with the latter being a game with key questions and situations from real-life. The idea is for people to read statements and discuss them in groups.

Interest in the campaign and its material has grown. Today a knowledge portal has been built, where all the material is collected. 'We could be out there constantly lecturing. Thanks to \#MeToo, awareness has grown. When we started the campaign, there was a skepticism from industry colleagues. It doesn't exist any longer. I feel that there is an understanding that we need to change the jargon in order to become a more attractive industry', says Hessel. 


\section{Sources}

Björnberg, U., Ottosen, M.H. (Eds.), (2013). Challenges for future family policies in the Nordic countries. (13:38). Copenhagen: SFI - Danish National Centre for Social Research.

European Institute for Gender Equality (EIGE), (2019). Gender Statistics Database.

European Network of Equality Bodies (Equinet), (2017). Equinet Members.

European Union (EU), (2017). 2017 Report on equality between women and men in the EU.

EUROSTAT, (2019). How much is spent on family benefits in the EU?

Forum for Mænds Sundhed, (2017). Fædres sundhed. En undersøgelse ved Forum for Mænds Sundhed.

Gíslason, I.V., and Björk, E.G. (Eds.), (2010). Föräldraledighet, omsorgspolitik och jämställdhet $i$ Norden. (TemaNord, 2010:595). Copenhagen: Nordic Council of Ministers.

Halrynjo, S., Kitterød R. H. (2016). Fedrekvoten - norm for fedres permisjonsbruk i Norden. En litteraturstudie. (2016:06). Oslo: Institute for Social Research.

Halrynjo, S., Teigen, M. (Eds.), (2016). Ulik likestilling i arbeidslivet. Gyldendal Akademisk.

Hardoy, I, Schøne P, Misje Østbakken K. (2017). Children and the gender gap in management. Labour Economics.

Heikkilä, M. (2013). Hållbart jämställdhetsarbete $i$ förskolan och skolan i Norden - med lärande exempel (TemaNord 2013:557). Denmark: Nordic Council of Ministers.
Heilman, B., Levtov, R., van der Gaag, N., Hassink, A., Barker, G. (2017). State of the World's Fathers: Time for Action. Washington, DC: Promundo, Sonke Gender Justice, Save the Children, and MenEngage Alliance.

International Labour Organization (ILO), (2017). ILOSTAT database.

International Network on Leave Policies and Research, (2017). Leave Network Reports.

Løvslett Danbolt, I. (2016) The ultimate balancing act: Work and family in the Nordic region.

Denmark: Nordic Council of Ministers.

Løvslett Danbolt, I. (2016). All about business: Nordic women on boards and in leadership. Denmark: Nordic Council of Ministers.

Lundberg, U. (2006). Tankar om den nordiska modellen. Report to the Council of Nordic Trade Unions (NFS). Stockholm: Institute for Futures Studies.

Nordfjell, O.B. \& Nielsen, S. B. (2011). Hvordan har det blitt 8400 menn ansatt i norske barnehager? S. B. Nielsen (Ed.), Nordiske mænd til omsorgsarbejde. Roskilde: Nordic Council of Ministers.

Nordic Information on Gender (NIKK), (2014). Heltid eller deltid? Olika förutsättningar för kvinnor och män i Norden. Faktablad från projektet Deltid $i$ Norden.

Nordic Information on Gender (NIKK), (2016). Därför stannar papporna hemma. Faktablad om föräldraförsäkringssystemen i Norden.

Nordic Information on Gender (NIKK), (2017). Gender Equality Policy.

Nordic Information on Gender (NIKK), (2017). Iceland intent on eliminating the gender pay gap. 
Nordic Information on Gender (NIKK), (2017). Important Years: Important dates for gender equality in the Nordic countries.

Nordic Information on Gender (NIKK), (2017). Joint feminist struggle changed society in the Nordic region.

Nordic Statistics, (2019). Gender Equality Indicators.

NOSOSCO, (2015). Table 3.16: Social Protection in the Nordic Countries 2013/14: Scope, Expenditure and Financing. Copenhagen: Nordic Council of Ministers.

NOSOSCO, (2017). Table 3.15: Social Protection in the Nordic countries 2015/2016: Scope, Expenditure and Financing. Copenhagen: Nordic Council of Ministers.

NOSOSCO, (2017). Table 3.19: Social Protection in the Nordic countries 2015/2016: Scope, Expenditure and Financing. Copenhagen: Nordic Council of Ministers.

OECD, (2016), Society at a Glance 2016: OECD

Social Indicators, Paris: OECD Publishing.

OECD, (2016). Be Flexible! Background brief on how workplace flexibility can help European employees to balance work and family.

OECD, (2018). LMF2.4: Family Friendly Workplace Practices. OECD Family Database.

OECD, (2019). PF3.1: Public spending on childcare and early education. OECD Family Database.

OECD, (2019). PF3.2: Enrolment in childcare and pre-school. OECD Family Database.

OECD, (2017). PF2.1: Key characteristics of parental leave systems. OECD Family Database.
OECD, (2017). PF2.2: Use of childbirth related leave by mothers and fathers. OECD Family Database.

OECD, (2017). The pursuit of gender equality: An uphill battle. Paris: OECD Publishing.

OECD, (2018). Is the Last Mile the Longest? Economic Gains from Gender Equality in Nordic Countries. Paris: OECD Publishing.

Regnö, K. (2013). Det osynliggjorda ledarskapet. Kvinnliga chefer i majoritet. (Doctoral thesis). Stockholm: KTH Royal Institute of Technology.

Teigen, M. (Ed.), (2015): Virkninger av kjønnskvotering i norsk næringsliv. Oslo: Gyldendal Akademisk.

The briefs are also based on interviews with researchers. 



\section{About}

Nordic Solutions to Global Challenges is an initiative by the Nordic prime ministers to enable knowledge sharing and exchange under three pillars, namely: Nordic Green, the Nordic Gender Effect and Nordic Food \& Welfare. The initiative is part of the Nordic region's effort to promote progress towards the UN's Sustainable Development Goals through the Nordic Council of Ministers, the official arm of Nordic governmental cooperation. The Nordic Gender Effect at Work is the name of the prime ministers' flagship to promote gender equality as a goal in its own right, and as a prerequisite for decent work and economic growth.

This series of briefs was prepared by Nordic Information on Gender (NIKK). NIKK is a knowledge centre, which collects and disseminates Nordic research, knowledge and policy in the area of gender equality.

The briefs describe how the Nordic countries have facilitated women's participation in the labour market and promoted gender equality at large. The introduction provides an overview of the Nordic welfare model and a historical context for the solutions that have been developed in the Nordic region over time. There are four specific briefs, which outline policies and experiences on subsidised childcare for all, shared and paid parental leave, flexible work arrangements and measures to achieve gender balance in leadership and equal opportunities at work.

\section{Acknowledgements}

The Nordic Council of Ministers would like to acknowledge and give special thanks to the International Trade Union Confederation (ITUC) and UN Women for contributing with invaluable feedback to the briefs, and to the International Labour Organization (ILO) for the collaboration on the Global Dialogue on Gender Equality in the World of Work, which provided an invaluable foundation for the series.

Thanks to all contributors including author Ida Måwe, flagship project initiator Julia Fäldt Wahengo, lead editors Line Christmas Møller, Elin Engström and Anna Rosenberg, as well as Ulrika Jansson, Kajsa Widegren, Maria Grönroos, Josefine Alvunger, Sanna Schiller, Ned Lawton, Ulla Agerskov, Frida Thomassen, Idah Klint, Sigtona Halrynjo, Johanna Lammi-Taskula, Ingólfur V. Gíslason, Ulla Björnberg, Tine Rostgaard, Charlotta Niemistö, as well as the flagship steering committee and the Nordic Committee of Senior Officials for Gender Equality.

\section{For more:}

norden.org/nordicgendereffect and nikk.no 
Nordic Council of Ministers

Nordens Hus

Ved Stranden 18

DK-1061 Copenhagen

www.norden.org

Promoting gender equality at work is not only a matter of rights; it is the smart thing to do from the perspective of inclusive growth. The Nordic region is a case in point, as it has come to represent the 11th largest economy in the world, not despite policy commitments to gender equality and social justice, but because of it. The Nordic countries have robust economies and good living conditions, where both women and men have high labour force participation rates. However, the gender pay gap is persistent and occupational segregation continues to hinder gender equality.

The Nordic Gender Effect at Work briefs share the collective Nordic experience in investing in gender equality including parental leave, childcare, flexible work arrangements, leadership and equal opportunities at work, and seek to make further progress through cooperation.

\section{\#nordicsolutions to global challenges}

